\title{
Assessing and managing sustainability in international perspective: corporate sustainability across cultures - towards a strategic framework implementation approach
}

Martin Gerner ${ }^{1,2}$

\begin{abstract}
Introduction: Sustainability constitutes an essential element in corporate contexts by now. Corporate sustainability may be addressed differently, either selectively or integrated. The holistic approach opted for primarily focuses on conveying aspects of corporate sustainability across different socio-cultural contexts. In doing so, the full quadruple scope of sustainability dimensions is considered cornerstone of a well-chosen case-study design. Such particular reference prototypically exemplifies business models in highly volatile commodity markets. Continuously longing for optimization and rationalization due to creativity and productivity gains, the company is predominantly challenged by changing customer needs resulting from digitization as mega trend of the twenty-first century.

Case description: Alluding to the business of stationery and professional office supplies, this case study aims at advocating the systematic proceeding of how to strengthen corporate sustainability through both embracing existing and evolving culture-bound approaches of sustainability vis-à-vis a framework implementation strategy and related guidelines for implementation at operational level. The essential quest is how to convey aspects of corporate sustainability across different socio-cultural contexts? Aiming at contributing to some kind of framework implementation strategy this implies reflecting upon assessing the status quo of corporate sustainability-related strategic approaches, activities and initiatives, means and instruments (sustainability performance); identifying universal and culture-bound drivers (sustainability opportunity); and deducing operational guidelines towards stakeholder awareness, selected strategic options, projects and best practices (sustainability commitment).

Given the theoretical background of corporate sustainability and related contexts, impetus for operationalizing is created by triple means of:

- Adopting an extended and generic life-cycle assessment (LCA) as core analytic framework and structuring element, corresponding with the value-chain-oriented approach of business segments,

- Applying the multi-method paradigm of methodological triangulation, including stakeholder observation, expert interviews and company resources, and

- Framing major characteristics as case study according to principles of qualitative content analysis.

(Continued on next page)
\end{abstract}

Correspondence: martin.gerner@tu-dresden.de

${ }^{1}$ Culture and Foreign Policy, Institut für Auslandsbeziehungen (ifa), Stuttgart,

Germany

${ }^{2}$ Technische Universität Dresden, Dresden, Germany 
(Continued from previous page)

Discussion and evaluation: Assuming that corporate sustainability may be conducive to foster innovation and evolution of products and services, the company's sustainability performance, sustainability opportunity and sustainability commitment is systematically analysed in line with the generic life cycle. By covering supply chain, production, distribution/packaging, service/use, and end-of-life, the status quo of corporate sustainability-related strategic approaches is assessed first, followed by identifying universal and culture-bound drivers to corporate sustainability, and concluding operational guidelines in terms of stakeholder awareness, selected strategic options, projects and best practices. A resultant framework implementation strategy provides four strategic options of product stewardship, operational efficiency, innovative transformation, and adaptive responsiveness, and attributing them to cross-sectoral aspects of innovation, business-model evolution and socio-cultural contexts, first and foremost.

Innovative value is added by systematically and holistically assessing corporate sustainability driven by grounded heuristics, multi-dimensional and culture-inclusive rationale, and implementation-focused impetus.

Conclusions: It can be concluded that adequately taking socio-cultural contexts into consideration may constitute a strategic and influential driving force to corporate sustainability, that strengthening cultural aspects of corporate sustainability may push the innovative capacity for business-model evolution; and that highlighting comparative advantages of sustainability-oriented manufacturing and branding favours the identification of business cases for sustainability.

In a nutshell, corporate commitment to/for sustainability is essentially advised in challenging times of economic turbulence and rapid changes; it represents the window of opportunity to revisit assumptions and value propositions of long-lived business models.

Keywords: Sustainability, Corporate sustainability, Corporate responsibility, CR, CSR, Sustainability assessment, Life-cycle assessment, LCA, Strategic, Performance, Opportunity, Commitment, Universal, Cultural, Framework implementation strategy

\section{Introduction \\ Framing}

Companies are increasingly considering corporate sustainability conditio sine qua non within their respective portfolio of economic activities (Schaltegger, Harms, \& Windolph, 2010, 34 et seqq.). Either selectively addressed through means of corporate (social) responsibility (Altenburger, 2013; Asif, Searcy, Zutshi, \& Fisscher, 2013, p. 9), or integrated into comprehensive strategic considerations (Stanger, 2017; Woeckener, 2014; see Fig. 1: Corporate (Social) Responsibility subsumed under Corporate Sustainability (adapted from Amini \& Bienstock, 2014, p. 13; Gerner, 2013, p. 157; Steinkellner, 2016b, p. 5)), corporate sustainability management is increasingly challenged by fundamentally changing market conditions, particularly in terms of innovation and business-model development (evolution) on the one hand, and socio-cultural contexts, on the other.

Taking Schumpeter's model of lean versus destructive innovation (Disselkamp, 2012; Krause, 2013; Schuh, 2013), that is incremental evolution versus disruptive leap-frogging (Nawrot, 2014, p. 116; Pohl, 1996, 5 et seqq.; Springer Fachmedien Wiesbaden, 2014, pp. 7576), commodity markets are highly volatile and constantly on the move longing for optimization and rationalization, mainly due to creativity and productivity gains (Cox \& Alm, 2018; Schumpeter, 1912/2006, 103 et seqq.; Steinkellner, 2016b, p. 6). Changing customer needs and proclaimed trends foster innovation and evolution of products and services (Larson, 2011; Vishwanath \& Barnett, 2011). Digitization is regarded the mega trend of the twenty-first century (Chuan et al., 2013; Keuper, Hamidian, Verwaayen, Kalinowski, \& Kraijo, 2013; Schallmo, Rusnjak, Anzengruber, Werani, \& Jünger, 2017); sustainability-related management is both affected by this innovation, and is at the same time driving it forward (Adams, Jeanrenaud, Bessant, Overy, \& Denyer, 2012; Ahrend, 2016; Gordon \& Nelke, 2017; Hilty, Jaeger, \& Lamping, 2012; Hoffmann, Knopf, Rotter, \& Richter, 2011; Horbach, 2005; Knopf, 2011; Müller-Prothmann \& Dörr, 2011; Stanger, 2016, 135 et seqq., 2017, p. 62). Both innovation systems share the high degree of interdependence leading to a shift from old-school technologies towards advanced business models of production and provision of services (Stampfl, 2016; Tokarski, Schellinger, \& Berchtold, 2016; Weinreich, 2016). This applies to manifold corporate contexts, in particular those with high percentages of analogue, meaning non-digital value creation, such like paper-bound industries (MarketLine, 2013b, p. 15; Verband der PBS-Markenindustrie im FMI e.V., 2017b), for instance.

Adapting to socio-cultural contexts, i.e. cultural environments or landscapes of socialization affecting 


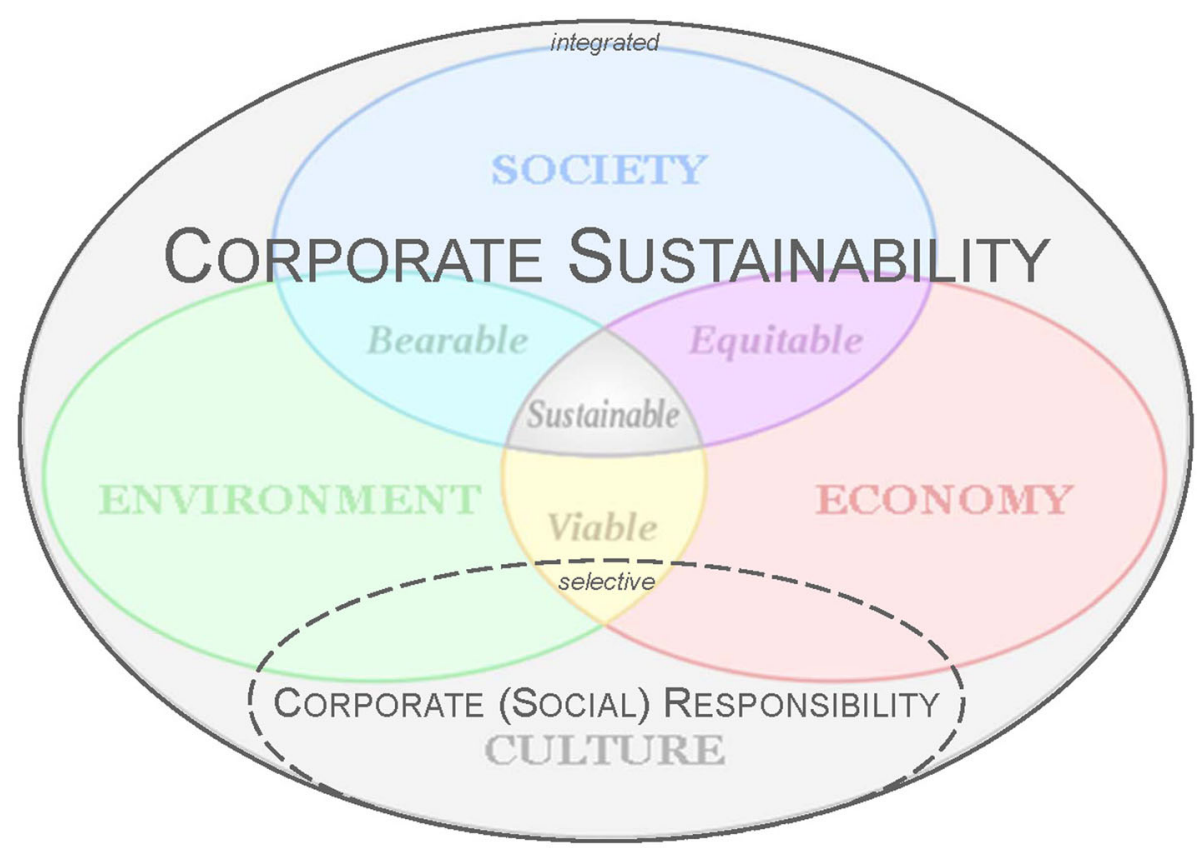

Fig. 1 Corporate (Social) Responsibility subsumed under Corporate Sustainability

individuals' behaviour due to learned values and shared attitudes, including modes of communication, norms, customs, ideas, beliefs and meanings, primarily constitutes a major, though frequently underestimated requirement to companies business-wise committed at global scale (Dessein, Soini, Fairclough, \& Horlings, 2015). Therefore, international business and management theories call upon value-chain-related managers to consequently account for cultural patterns and intercultural characteristics in order to succeed in culturally heterogeneous markets in the long run (Garner, 2016; Matzler, Pechlaner, \& Renzl, 2014; Pizzirani, McLaren, \& Seadon, 2014; Skjerven \& Reitan, 2017). Thus, what applies to general management needs to be reflected in sustainabilityrelated contexts, accordingly, since perceptions are deemed to vary considerably across cultural reference systems (Gerner, 2013, 24 set seqq., 417, 465).

\section{Objectives}

Taking into account the international dimension of corporate sustainability, the intention is to contribute to some kind of framework implementation strategy that correlates corporate with culture-bound sustainability, that highlights industry-sector-specific characteristics, and that conceptualizes conferrable strategic options of corporate sustainability. This case study aims at strengthening corporate sustainability through both embracing existing and evolving culture-bound approaches of sustainability vis-à-vis a framework implementation strategy that provides guidelines for implementation at operational level (Berns, Townend, Khayat, Balagopal, \& Reeves, 2009, p. 7; Engert \& Baumgartner, 2016; Khalili, 2011b, pp. 152-154).

The essential quest is how to convey aspects of corporate sustainability across different socio-cultural contexts? Hence, aiming at contributing to some kind of framework implementation strategy this implies reflecting upon:

- Assessing the status quo of corporate sustainabilityrelated strategic approaches, activities and initiatives, means and instruments - What is the current state of corporate sustainability like? (sustainability performance); - Identifying universal and culture-bound drivers by means of SWOT-analysis, analysis of potential, stakeholder mapping and communication - Which are key drivers to increase corporate sustainability across sociocultural contexts? (sustainability opportunity);

- Deducing operational guidelines towards stakeholder awareness, selected strategic options, projects and best practices - Which feasible conclusions can be proposed? (sustainability commitment) (Allen, 2016; Allen \& Craig, 2016; Brugger, 2010; Hill \& Westbrook, 1997; O'Neill, Hershauer, \& Golden, 2006, p. 35; Osburg, 2012; Van den Berghe, Lutgart, Spitzeck, Hansen, \& Grayson, 2011; Weihrich, 1982).

Derived from an existing business-case scenario examined in the course of a major research project, this paper primarily aims at putting the conceptual approach of 
analysis up for further scholarly debate. Given that notion purposefully exempts from directly attributable reference to the case itself, e.g. disclosing and discussing case-related characteristics, facts and figures.

In a nutshell, an academic void is addressed by systematically assessing corporate sustainability based on a) grounded heuristics (life-cycle assessment (LCA) through qualitative content analysis), b) the multi-dimensional and culture-inclusive rationale, and c) an implementationfocused impetus.

\section{Theory}

Embracing sustainability as priority of corporate management involves manifold motivations. Those can roughly be subsumed under push-pull factors (Schaltegger et al., 2010, pp. 34-35; Schaltegger, Hörisch, Windolph, \& Harms, 2012, p. 19). Push factors determining corporate sustainability are relevant legislative provisions or awareness raised within society, for instance, suited for exerting certain pressure of legitimation. Pull factors are favourable market conditions, inter alia, deemed to induce companies towards sustainability commitment. In other words, do companies rather anticipate beneficial potentials of realizing promising market opportunities intrinsically, than being extrinsically forced to comply with external requirements? Affiliated with established research objectives, the underlying research questions are:

1) Does considering socio-cultural contexts constitute a strategic driving force with regard to corporate sustainability (pull factor)?

2) Does strengthening cultural aspects of corporate sustainability increase the innovative capacity for business-model development (pull factor)?

3) Does highlighting comparative advantages of sustainability-oriented manufacturing and branding favour the identification of business cases for sustainability (push factor)?

Taking a look at the overall research interest of how to convey aspects of corporate sustainability across different socio-cultural contexts, different references to respective theories are considered relevant:

1) Corporate sustainability needs to be elaborated in conjunction with its contesting concepts, such like sustainable entrepreneurship or corporate (social) responsibility;

2) Corporate contexts stemming from the chosen business case need to be introduced, including marketing in business-to-business relations, business segments in sustainability contexts, and culturebound or intercultural notions of sustainability.
The rationale behind addressing corporate sustainability and related corporate contexts is to establish a theory-based reference framework that is essential prerequisite to analyse corporate sustainability performance (Horbach, 2005; The European Federation of Financial Analysts Societies, 2009) through addressing relevant topics in connection with corporate sustainability management characteristics.

1) Corporate Responsibility (CR), Corporate Social Responsibility (CSR), Corporate Citizenship (CC), Corporate Sustainability (CS), company-related sustainability still remains some blurring, ambiguous concept. Depending on the corporate point of view, there is a considerable range of notions of how corporate sustainability is to be defined and implemented. Differing understanding ultimately results from alternative sources or disciplinary origins sustainability is approached; thus, underlying assumptions comprise of moralethical, societal-corporative, legal or managerial aspects emphasized, respectively (Bansal \& Song, 2017, pp. 119-122; Wilson, 2003, p. 2).

Acknowledging the variety of notional strands (Bansal \& Song, 2017, p. 130; Engert, Rauter, \& Baumgartner, 2016, p. 2834; Schaltegger, 2011a, p. 187; Stanger, 2016, 57 et seqq.), least common consensus might certainly be achieved by considering corporate sustainability as moving target (Schaltegger \& Burritt, 2005, p. 193). Given the prevalent inconsistency of use, scholars by trend argue for an integrated definition: In order to be effective, sustainability must be integrated into organizational goals, internal incentives and evaluation systems, and organizational decision-support systems, above all (Amini \& Bienstock, 2014, p. 14; Baumgartner, 2004, 26 et seqq.; Krause, 2016, p. 51; Morioka \& de Carvalho, 2016, p. 140).

Referring to corporate sustainability or sustainable entrepreneurship, respectively, for business-model development (Choi \& Gray, 2008, 558, 559; Gast, Gundolf, \& Cesinger, 2017; Hockerts \& Wüstenhagen, 2010, 5 et seqq.; Schaltegger, 2011a, p. 189; Weidinger, Schmidpeter, \& Fischler, 2014, p. 1), it is considered pivotal to elucidate from scratch the conceptual differences in corporate (social) responsibility (Amini \& Bienstock, 2014, p. 13; Asif et al., 2013, p. 8; Bansal \& Song, 2017, 116, 122; Beschorner, 2012; Buchholtz, Brown, \& Shabana, 2009; Carroll, 2016; Crane, McWilliams, Matten, Moon, \& Siegel, 2009, p. 6; Finch, 2015, pp. 228-229; Idowu, Capaldi, Zu, \& Gupta, 2013, vii; Lantos, 2001, 595, 598 et seqq.), corporate citizenship (Schaltegger, 2011b, p. 53), and corporate sustainability (Schaltegger, 2011a, p. 189; Schaltegger \& Harms, 2013, p. 14) as corresponding 
umbrella term (Amini \& Bienstock, 2014, p. 13; Lantos, 2001, 595 et seqq.; Prexl, 2010, 86 et seqq.; Schaltegger, 2011b, pp. 52-53).

Important to note first is the normative progress from corporate responsibility towards corporate sustainability, thus inextricably linking responsibility with sustainability. As a result, corporate sustainability reaches beyond corporate responsibility in conceptual terms (Bansal \& Song, 2017, p. 130; Schaltegger, 2011a; Schaltegger \& Petersen, 2009, p. 70). Second, the entire dimensional scope of sustainability is considered (Baumgartner \& Rauter, 2017, p. 84; Elkington, 2002, 69 et seqq.; Gerner, 2013, p. 154; Jeurissen, 2000, p. 229), including cultural aspects, notably. Third, corporate sustainability is implementation-oriented, because "if corporate social responsibility (CSR) is to exceed the ambition of a general philosophy or to be more than (public relations), corporate sustainability management is required" (Schaltegger \& Petersen, 2009, p. 67). In this respect, sustainabilityrelated activities of companies must necessarily be attached to the economic logic (Schaltegger, 2011a, p. 196), so as to accomplish the comprehensive integration of corporate sustainability into strategic management (Engert et al., 2016, 2834 et seqq.). Put differently, "corporate sustainability can be seen as the result of management attempts to tackle sustainability challenges" (Schaltegger \& Burritt, 2005, p. 195). Fourth, corporate sustainability as long-term target requires structural embedding of key elements into strategic plans - striving for business cases for sustainability (Engert \& Baumgartner, 2016, p. 826; Khalili, 2011c; Morioka \& de Carvalho, 2016, p. 141; Schaltegger, 2017, 85 et seqq.; Wunder, 2017, 3 et seqq.), and/or modelling of fully-fledged corporate sustainability strategies - aligning with the value proposition alongside the value-adding chain (Lloret, 2016, 420 et seqq.). Fifth, both instances considered business case and strategy respectively - corporate sustainability governance gains increasing importance as normative driving force (Fischer, 2017, 135 et seqq.; Viardot, 2017, 78, 108)

To conclude, corporate sustainability can be regarded as the overarching integrated concept that incorporates the selective portfolio of corporate (social) responsibility (Stanger, 2017, p. 62), and which is to be implemented through sustainable entrepreneurs, after all (Asif et al., 2013, p. 9). What links related concepts with corporate sustainability is an increasing degree of holism, strategic orientation and normativity, ranging from selective-impulsive-intuitive to integrated-scaling-notional.

As to the research agenda, a thoroughly normative (1) approach towards cross-cultural corporate sustainability (2) is envisaged, focusing on feasibility (3), addressing strategic embedment (4), and incorporating aspects of governance through connecting frameworks or guidelines (5).

2) Contexts do matter - approaching corporate sustainability in the proposed holistic way (Herlyn \& Radermacher, 2014, p. 453; Meffert \& Hensmann, 2014, p. 24; O'Neill et al., 2006, p. 34; Schröder, Holbach, \& Müller-Kirschbaum, 2014, p. 258) the principal insight gained is normativity (Habisch \& Bachmann, 2016, p. 9). Setting standards, rules or procedures requires deciding and implementing power, above all, that represents one major element to be achieved through strategic management. The resulting question is which particular corporate contexts need to be taken into account that influence or drive sustainability-related management? In other words, which framing concepts need to be considered, explained or introduced further? Arguing deductively, i.e. from the general to the specific, three significant contexts find their way into the theoretic framework, consisting of: a) Marketing in business-to-business relations

Performing economically in a business-to-business environment, i.e. relationships between organizations (Backhaus, 2015, pp. 19-20; Kesting, Kliewe, Korff, \& Serbin, 2014, pp. 5-6; Schallmo, 2013, pp. 17-18), requires specific management decisions - so-called entrepreneurial agility (Backhaus \& Muehlfeld, 2015, pp. 9798; Backhaus \& Voeth, 2015, pp. 17-19; Mishra, 2017, 110 et seqq.) - in terms of differing bilateral transfer potential compared to business-to-consumer (b2c) marketing (Kesting et al., 2014, p. 6; Klarmann \& Fleischmann, 2014, p. 4), self-contained transaction processes or brand management/policy (Baumgarth, 2010a, 2010b, pp. 4849, 2014; Baumgarth \& Binckebanck, 2010), resulting from indirect or derivative demand combined with informational uncertainty about end customers, in particular (Backhaus, 2015, 17 et seqq.; Backhaus \& Muehlfeld, 2015, pp. 97-98; Backhaus \& Voeth, 2015, p. 21; Baumgarth, 2010b, pp. 48-49; Budt \& Lügger, 2013, 68 et seqq.; Kliewe \& Kesting, 2014, 5 et seqq.; Rusnjak, 2014; Weber, Bramsemann, Heineke, \& Hirsch, 2017, p. 21; Weiber \& Wolf, 2014, 23 et seqq.); thus, customerrelationship management (CRM) translates into stakeholder management (Backhaus \& Voeth, 2015, p. 21); Budt \& Lügger, 2013, p. 69; Komoto \& Mishima, 2013) aiming at anticipating and reconciling both supplier and buyer culture through business-segment-integrating marketing (Cadden, Marshall, \& Cao, 2013, 88-89, 94; Homburg, 2017, 1066 et seqq.; Mishra, 2017, pp. 91-93; Weiber \& Wolf, 2014, 24 et seqq.).

Conventionally, product-oriented marketing (Backhaus \& Muehlfeld, 2015, pp. 103-105) can be attributed to 
five immanent driving factors, enablers or key drivers defined as factors which cause/influence particular phenomena to happen or make progress/develop - towards business success, comprising of (Albers \& Krafft, 2013, 10 et seqq.; Baan \& Homburg, 2013; Backhaus \& Muehlfeld, 2015, 94 et seqq.; Binckebanck, 2013, 8 et seqq.; Budt \& Lügger, 2013, 68 et seqq.; Homburg, 2017, 143 et seqq.; Kirchhof \& Nickel, 2014; Lun, Lai, \& Cheng, 2010, 77 et seqq.; Ternès \& Runge, 2015, pp. 1-12):

1) Trust: Opting for long-term customer-relationshipmanagement (CRM) evoking sentiments of willingness and ability to serve;

2) Brand reputation: Developing and streamlining an increasingly important branding consistent with the content-based value proposition and applicable both internally for staff and externally for customers;

3) Unique-selling-proposition (USP): Elaborating the unique idea or feature for value proposition, making the decisive difference from competitors in the customers' eyes;

4) Marketing-sales-interface: Incorporating different enriching perspectives of expertise and experience for market cultivation, ranging from product or brand orientation to customer contacts or sales success;

5) Incentive systems: Thinking of how to measure and value performance conventionally and alternatively (Berndt, 2016, 22 et seqq.; Berndt \& Henkel, 2016, 26 et seqq.; Homburg, 2017, 1080 et seqq.; MarketLine, 2014, p. 14).

Correlating corporate responsibility with the aforementioned elements of branding in business-to-business (b2b) contexts (Baumgarth \& Binckebanck, 2010, 487, 493; Klarmann \& Fleischmann, 2014, p. 337), sustainable branding (Meffert \& Rauch, 2014, 159 et seqq.) attains considerable importance in the context of sustainability to be dealt with as driving issue of strategic brand management (Baumgarth, 2014; Belz, 2010, 59, 63 et seqq.; Chao, Polonsky, \& Jevons, 2009, p. 341; Popoli, 2011). "In this way, attempting responsible branding (...) can result in organisations reviewing their overall (corporate) impact, not simply focusing on narrowly defined issues, which has the potential for considerable advantage to society as a whole" (Chao et al., 2009, p. 334). In consequence, sustainability enters as driving factor into the business-to-business (b2b) and the corresponding branding network context (Lacoste, 2016, pp. 152-154), respectively:

6) Sustainability performance: Adopting means of corporate sustainability in a strategic manner significantly redounds to innovation potential and business success (Glaser \& Hassler, 2015, pp. 6-7; Stanger, 2017, 61-62, 64). It "reflects one target end of the move of companies in the corporate responsibilities continuum from corporate conformance and compliance with given standards to corporate performance in relation to stakeholder expectations. In this context, sustainability performance can be defined as the performance of a company in all dimensions and for all drivers of corporate sustainability" (Schaltegger \& Wagner, 2006, p. 2). This "progressive management approach (...) generates new products and services, management systems, markets and organisational processes that increase the social as well as the environmental value of business activities" (Weidinger \& Schmidpeter, 2014, p. 2).

Hence, sustainability needs to be an embedded element of the corporate narrative, meaning that it ought to be incorporated into the brand essence, already (Baumgarth, 2014, p. 220; Lahme \& Klenk, 2014, p. 156). Addressing sustainable branding strategically leads to sustainable marketing (Bruhn, 2015, 337 et seqq.; Chao et al., 2009, 334 et seqq.; Eggert, Haas, Ulaga, \& Terho, 2015, 488 et seqq.; Kenning, 2014, 6-7, 11-16, 17, 19; Meffert, Kenning, \& Kirchgeorg, 2014). To recap, sustainability-oriented marketing (sustainability marketing) is regarded key to business success of globallyengaged brand manufacturers (Herlyn \& Radermacher, 2014, 435 et seqq.). Particularly if strategically underpinned, "(companies) that have undertaken planned, strategic and quasi-strategic (...) activities will be viewed more positively by stakeholders than (those) that have only used (corporate responsibility) tactically and piecemeal" (Chao et al., 2009, p. 342);

\section{b) Business segments in sustainability contexts}

Assessing the corporate sustainability performance implies having identified relevant areas in advance. In order to avoid piecemeal assessments on a purely individual basis because of not making sufficiently clear the nexus between product emergence and its chain of economic value added, business segments alongside the corporate value chain are selected and customized through lifecycle analysis, accordingly (Baumgarth, 2010a, 63 et seqq., 2014, 325 et seqq.; Baumgarth \& Binckebanck, 2010, 487, 493; Bruhn, 2015, 337 et seqq.; d'Heur, 2014b, pp. 3-4; Eggert et al., 2015, 488 et seqq.; Lacoste, 2016, p. 152; Meffert et al., 2014, 10 et seqq.; Schaltegger \& Wagner, 2011);

Business segments attached to sustainability contexts can best be identified and described alongside value creation. Accordingly, a corporate value chain may be 
considered the sum of business segments altogether contributing to value-adding, kicking off with the supply chain. Making value chains sustainable is the key to integrated corporate sustainability that eventually leads to sustainable product or service life-cycles (Bey, 2018, p. 530; Bouchery, Corbett, Fransoo, \& Tan, 2017; Herrmann, 2010, p. 118; Lahme \& Klenk, 2014, 155, 156; Moltesen \& Bjørn, 2018, 51 et seqq.; Nidumolu, Prahalad, \& Rangaswami, 2009, 2013, p. 2).

From a generic point of view principal business segments in manufacturing companies are:

- Supply chain: Sustainable supply-chain management encompasses more than collaborating on refining specifications and logistics; in fact, it is more about promoting product-oriented stewardship through aligning contractual incentives and applying sustainability-related criteria to select as well as maintaining strategic alliances and long-term partnerships with sustainability-driven suppliers (Aquilon, 1997, p. 85; Berning \& Venter, 2015, pp. 6257-6258; Bretzke \& Barkawi, 2010, p. 21; Cadden et al., 2013, pp. 87-88; Carter \& Rogers, 2008, 372, 377; Davis, MoraMonge, Quesada, \& Gonzalez, 2014, p. 188; Gold, Seuring, \& Beske, 2010, p. 142; Hudson, 2005; Lahme \& Klenk, 2014, p. 157; Pagell \& Wu, 2009, p. 39; Sabbaghi \& Sabbaghi, 2011, 109 et seqq.; Seuring \& Müller, 2008, p. 460; Walther, 2010, p. 247);

- Production: Both sustainable manufacturing and sustainable products are considered prerequisite to sustainable consumption based on user-producer interaction. Although manufacturing processes are often associated with centrepiece or core-value-creation of saleable products, upstream and downstream processes are equally important constituent parts of corporate sustainability (Baumgartner \& Rauter, 2017, p. 86; Hoffmann \& Hoffmann, 2012; Lee, 2013, 261, 267; Seliger, 2012; United Nations Environment Programme (UNEP) \& Delft University of Technology, 2006, 21, 63); - Packaging and distribution: Both elements are typically subsumed under the logistics terminology though addressing planned, developed, organized, coordinated, steered and controlled material or product flows. Sustainability-related packaging and distributing is commonly coined as sustainable logistics or green logistics, respectively (Aquilon, 1997, pp. 76-77; Bretzke, 2014; Carter \& Rogers, 2008, 370, 378; Deckert, 2016, 3, 23 et seqq.; Giudice, 2013, 323 et seqq.; Presse- und Informationsamt der Bundesregierung, 2011, p. 43);

- Use, maintenance and services: Commonly referred to consumption as the act or process of spending wastefully or utilizing purposefully scarce goods and services, in terms of corporate sustainability there is an observable shift from the classical product use towards a more functional approach. Changing from productselling business models to functional product-service systems is considered to significantly reduce negative ecological and social impacts of the product. As a result, business models supporting product-service systems are increasingly evolving; they provide "( ...) an integrated mix of products and services that are together able to fulfil a particular customer demand (to deliver a 'unit of satisfaction'), based on innovative interactions between the stakeholders of the value-production system (satisfaction system), where the economic and competitive interest of the providers continuously seeks environmentally and socio-ethically beneficial new solutions" (Barquet, Cunha, Oliveira, \& Rozenfeld, 2012, pp. 189190; Baumgartner \& Rauter, 2017, p. 90; Khalili, Melaragno, \& Haddadian, 2011, 207 et seqq.; Komoto \& Mishima, 2013, pp. 634-635; Kwak \& Kim, 2013, 177 et seqq.; Maxwell, Sheate, \& van der Vorst, 2006, 1468, 1471; Roy, 2000, p. 291; Sakao, 2013, 600 et seqq.; Vezzoli, Ceschin, Diehl, \& Kohtala, 2015, p. 2);

- End-of-life: Product-related end-of-life strategies fulfil a dual role: Optimizing the initial lifetime, and providing product lines with end-of-life systems. Boundaryspanning processes are envisaged through integrating both users/customers and involving stakeholders. Provided essential assumptions on the fully-fledged manufacturing process, the value-chain basis ought to be extended to high added-value end-of-life strategies, ranging from re-use, re-manufacturing or re-furbishing, re-cycling, incinerating, and/or considering local collection or recycling systems, both in formal and informal contexts. Undoubtedly, direct re-use is principally regarded a logistics and monitoring issue, whereas remanufacturing aims at re-gaining the initial functional performances of the product (Albers, Canepa, \& Miller, 2008, 54 et seqq., 98-99; Bauer, Brissaud, \& Zwolinski, 2017, 115, 126; Gauthier, 2005; Gemechu, Sonnemann, Remmen, Frydendal, \& Jensen, 2015, p. 39; Hoffmann \& Hoffmann, 2012; Sonnemann \& Margni, 2015; United Nations Environment Programme (UNEP) \& Delft University of Technology, 2006, 66, 69, 110 et seqq.).

Managing business segments alongside value chains in sustainability-oriented contexts demands strategy-driven and implementing momentum. Such sustainability strategies ensure long-term performance required to establish sustainability as determinant driver of innovation and business success, ultimately. Contexts influence formulating sustainability strategies in a dual, pushing and pulling, way (Khalili, 2011a, 23 et seqq.; Orsato, 2014; Schröder et al., 2014, 259 et seqq.; Stanger, 2017, pp. 62-63; Viardot, 2017, pp. 1-2). To conclude, modelling a competitive sustainability strategy requires first, a 
strategic management approach in due consideration of the value-adding business segments and second, the capability of recognizing relevant sustainability contexts as drivers for business success. Screening the product's performance, implementation needs then to be based on primary and secondary activities of policy-setting, following an integrated value-chain-management approach towards sustainability (Gemechu et al., 2015, p. 39; Lozano, 2012, p. 15; Porter, 1985/2004, 317 et seqq.; Porter \& Kramer, 2006; van Hemel, 1998, p. 41). Prioritized areas need to be embedded into or subsumed under a corporate strategy for sustainability (Viardot, 2017, 91 et seqq.);

\section{c) Culture-bound notions of sustainability}

Assuming the linkage between performance, context and culture, the cultural dimension is explicitly addressed in order to draw attention to the emerging discourse on cultural/intercultural aspects. More precisely, joined with the case study, how is corporate sustainability managed across culture, either driven through standardizing or differentiating strategies (Archer \& Cameron, 2009b; Ayman \& Hartman, 2011, 72 et seqq.; Barmeyer, 2009; Dessein et al., 2015, p. 30; Habisch \& Schmidpeter, 2016; Hofstede, Hofstede, \& Minkov, 2010; Lewis, 2000; Moray, 2004; Morioka \& de Carvalho, 2016, p. 140; Schaltegger, Windolph, Harms, \& Hörisch, 2014; Steinkellner, 2016a; Tilt, 2016, 2 et seqq.; Trompenaars \& Hampden-Turner, 2012; Weidinger et al., 2014). "Generally, culture is referred to as an emergent grouping of beliefs, knowledge, practices, values, ideas, language and worldviews within a social group; each of these elements affects the social group's ongoing attitudes and behaviour. However, culture is not bound to a given geographical location or fixed in time. Indeed, culture is often thought of as an intergenerational concept. Nevertheless, culture's broad range of definitions and uses also exposes its inherent complexity due to its distinctly dynamic nature" (Pizzirani et al., 2014, p. 1317). The broad notional scope particularly applies to transnational-corporate and sustainability contexts.

Culture enables facilitating identity and providing orientation, antagonizing cultural alienation in times of lacunae of normativity and creating meaning in a globalized world. Directed by cultural codes societal groups diverge to the extent of being culturally adapted and conditioned (Habisch, 2016, p. 197; Habisch \& Bachmann, 2016, 9 et seqq.; Lewis, 2000, 41 et seqq.; Santamaria, Escobar-Tello, \& Ross, 2016, p. 17). Such established software(s) of the mind can be captured as set of cultural dimensions, cultural layers or cultural patterns, respectively (Anbari, Khilkhanova, Romanova, \& Umpleby, 2010, p. 2; Aquilon, 1997, 80 et seqq.; Hofstede et al., 2010, 24 et seqq., 53 et seqq.; Moll, 2012, p.
43; Trompenaars \& Hampden-Turner, 2012, 123 et seqq., p. 21). According to cultural theory most of the cultural source code is not visible or observable, at first glance (Marsden, 2018; The Business Zoom, 2015). Doing business in specific and diffuse cultural backgrounds bears the risk and challenge of colliding cultural codes. Such cultural overlapping situations may potentially result in critical incidents. Managing successfully across cultures requires intercultural competence that includes context-specific communication skills (Lewis, 2000, 182 et seqq.; Tilt, 2016, 2 et seqq.; Trompenaars \& Hampden-Turner, 2012, 75 et seqq.).

Is culture linked to sustainability, if so, how? Recalling the dynamic and evolutionary nature, culture can be understood as mental model that emerges through longterm programming, commonly known as cultural evolution (Brocchi, 2016, pp. 52-66). In this respect, culture is far more than human variable or add-on (Chapanis, 2004; Kaplan, 2004, xii), it has always been the driver for transformation. Sustainability is widely recognized as transformational; hence, cultural codes and sustainability constitute the nexus of the mental construct of cultural transformation. Put into a nutshell, "(c) hanging user's existing habits, beliefs and activities, and creating new ones for sustainability requires a deep cultural transformation a 'transition of minds' rather than purely technological innovations" (Santamaria et al., 2016, p. 17).

Culture has evolved from niche topic into meaningful driver of the international policy framework (Arizpe, 2015, 18, 123; Dessein et al., 2015, p. 15). Over the intervening years, normative settings on the cultural dimension of sustainability have emerged, paying diligently heed to socio-cultural indicators, to the effect that culture turned into strategically positioning determinant in terms of (Dessein et al., 2015, p. 29), a) supportive and self-promoting role (culture in sustainable development), b) framing, contextualising and mediating mode (culture for sustainable development), and c) foundational and structural framework as underlying dimension (culture as sustainable development) (Brocchi, 2016, pp. 49-50; Ellson, 2004; Gerner, 2013, 24 et seqq., 33, 154; Kagan \& Kirchberg, 2016, p. 1489; Pizzirani et al., 2014, p. 1325; Romeiro Filho, 2015, p. 4698; Steinkellner, 2016b, p. 4).

To conclude, " $(t)$ he realization that sustainability cannot be conceived of without a cultural dimension and the argument that sustainability transformation requires wide-ranging cultural transformations is not particularly new, and a range of academic and policy discourses on culture and sustainability have developed over the past few decades" (Dessein et al., 2015, p. 1489).

Assuming culture and sustainability to be closely intertwined concepts, how do they apply to corporate context, put differently, in which way do they affect corporate sustainability? Since studies of comparing 
corporate-sustainability performance at global scale are progressively point of reference, the corporate-cultural question of sustainable development is highly relevant (Leszczynska, 2011, 341 et seqq.; Schaltegger et al., 2014). On the one hand, corporations are embedded into a macro-socio-cultural environment. In this regard, the nexus to the abovementioned culture as mental model applies, typically defined as "web of meanings made of repetitive habits and emotional responses which reflects the way the people feel, think, and perform" (Viardot, 2017, p. 9). On the hand, there is a micro-cultural level of distinct corporate cultures determining "how things are done through a set of behaviours, values, and visible symbols" within an entrepreneurial context (Handfield, 2013, 62 et seqq.; Trompenaars \& Hampden-Turner, 2012, pp. 103-104; Viardot, 2017, p. 9). Both scopes are interdependent, thus, many issues addressed are likewise important to both micro- and macro-cultural contexts, inter alia a) how to shape cultural change through addressing cultural sustainability in terms of heritage, vitality, socio-economic viability, diversity, locality, or nature-culture interfaces of eco-cultural civilization (Beschorner, 2006; Birkeland, Burton, Novoa, \& Siivonen, 2017; Dessein et al., 2015, 28 et seqq.; and b) how to manage cross-cultural stakeholder dialogues vis-à-vis minorities' participation and representation in the context of cultural landscapes, indigenous cultural or tribal values, and impacts resulting from corporate activities (Acosta, 2013, 106 et seqq.; CubilloGuevara, Hidalgo-Capitán, \& García-Álvarez, 2016, 34 et seqq.; Fatheuer, 2011, 26 et seqq.; Grimm \& Saner, 2011, 1-8, 247-258; Pizzirani et al., 2014, pp. 1318, 1325, Tilt, 2016, p. 4).

In conclusion, "sustainability is about developing a longterm perspective and approach to all business matters. The concept is best developed by those who genuinely care about progressing towards a more stable future for the benefit of all" (Schmidpeter \& Lewtas, 2016, p. 1). Due to that cultural sustainability ought to be attended/integrated more into economic models and embodied as source of creative resilience into corporate sustainability (Anbari et al., 2010, p. 1; Archer \& Cameron, 2009a, 179 et seqq.; Habisch \& Schmidpeter, 2016, 53 et seqq.; Kagan \& Kirchberg, 2016, p. 1490; Steinkellner, 2016b, 8 et seqq.; Viardot, 2017, 3 et seqq.). Collaborative cultures for sustainability stem from culture-sensitive, context-driven and performance-oriented business practices that show cultural sustainability as vibrant individual and organizational issue of corporate management (Archer \& Cameron, 2009b, 89 et seqq.; Dessein et al., 2015, p. 30; Moray, 2004, pp. 51-52; Morioka \& de Carvalho, 2016, p. 140). Related business cases displaying added value by addressing corporate responsibility and culture, and implementing cultural aspects into life-cycle analyses and assessments, respectively, are promising, predominantly affiliated to small-and-medium-sized enterprises (Hemmers, 2006, 127 et seqq.; Romeiro Filho, 2015, p. 468; Steinkellner, 2016a, 195 et seqq.). However, cultural sustainability is not yet considered an impact-category indicator; thus, recognition in related discourses is still rather limited (Paech, 2005, 57 et seqq.; Pizzirani et al., 2014, 1318, 1319); dealing with culture-bound notions of sustainability on the corporate level involves:

1) Ambiguity: Managing across cultural borders requires sustaining cultural uncertainty, even though doing business with global mind-sets. Tolerance to ambiguity is prerequisite to transnational solutions (Bartlett \& Ghosbal, 1987, 43, 51; Bartlett \& Ghoshal, 2008; Di Norcia, 1991; Guo, 2015; Keinert, 2008; Popoli, 2011, p. 426; Shister, 2004, p. 17; Solomon \& Schell, 2009, 217 et seqq.);

2) Branding: Universal versus particular is the frequently cited formula applicable to most strategy-related corporate contexts, most notably in formulating strategies within the scope of corporate responsibility. Diversified approaches tend to outweigh one-size-fits-all solutions of global branding which do not work for different markets, because "the legitimacy that companies seek through (corporate-responsibility) practices is obtained across multiple cultures and countries: Legitimacy is not just a home country phenomenon, it must be viewed globally. As a consequence, brand strategy must enhance both home and host country perspectives". In order to comply with the paradigm of cultural adapting and awareness, guidelines are proposed which encompass the identification of culturally relevant issues, acknowledgement of cultural heterogeneity, measurement, and interpretation (Chao et al., 2009, pp. 331-332; Harps, 2003, p. 85; Popoli, 2011, pp. 420, 430; Trompenaars \& HampdenTurner, 2012, pp. 31-32).

The following trends can be observed when summarizing the state of culture-integrating into corporate sustainability:

1) Approaches are mostly centred on supply chains. Despite acknowledging that "cultural complexities that can throw even the best managed global supply chains an unexpected curveball", the scope of cultural adaptiveness or cultural fit primarily relates to corporate cultures explaining differences between supplier versus buyer culture, for instance (Cadden et al., 2013, 86, 94-95; Davis et al., 2014, 190, 194; Hudson, 2005); 
2) In logistics and distribution practice, cultural differences are rather considered obstacles to global sourcing. Making this business segment work given increasing complexity requires further efforts of intercultural understanding in corporate relationship management (Aquilon, 1997, 77 et seqq.; Harps, 2003);

3) Cultural heterogeneity needs to be addressed to an increasing degree, particularly in international sales and operations planning (van Hove, 2013).

Internationally-operating corporations usually comprise global production and/or trading division structures, i.e. subsidiaries, branch offices and manufacturing sites, respectively. Consequentially, colliding cultures, intercultural encounters or critical incidents are typically and frequently met situations of companies in transnational/global business contexts. Culture can be both chance and challenge of international management. Many companies clearly accommodate cultural challenges as business opportunity; segments alongside the value chain do transversally capture sense-making as means of common corporate understanding. Corporate cultural responsibility is primarily attributed to driver of success through meeting the requirements of global stakeholders. However, culture is far more; it is creative resource to corporate evolution and sustainability, and should be planted into the core-business domain, accordingly. Corporate cultural responsibility ensures attractiveness of generations to come, and serves as source of workforce inspiration. Corporate marketing relies on culture in order to intensify the perception of products and services by adding a unique-selling aspect. Moreover, culture serves as foundation or least-common denominator that enables economic value creation and individual interaction, without the necessity of constantly negotiating for underlying values and beliefs (Fürst, 2014, p. 167; Schaltegger et al., 2014; Steinkellner, 2016a, 2016b, p. 11; Tilt, 2016, p. 4; Trompenaars \& Hampden-Turner, 2012, 186 et seqq.).

What can be learned from this theory approach: Is there anything like a normative narrative towards a sustainability shift in business paradigms (Ayman \& Hartman, 2011, 57 et seqq.)?

To conclude, on corporate-sustainability grounds, there is a notable trend from selective towards integrated notions of corporate responsibility corresponding to normative, culture-bound, implementing, strategically framed and aligned concepts of corporate sustainability. First of all, in terms of marketing in business-to-business (b2b) relations, another driver of competitiveness needs to be taken into consideration, adding up to trust, brand reputation, unique-selling-proposition, marketing-sales-interface, incentive systems, and sustainability performance. Once the corporate narrative of sustainability is incorporated into the brand essence, sustainable branding turns into sustainable marketing. Second, drawing on business segments, in sustainability-oriented contexts those need to rely on strategy and respective implementation alongside the value chains. Sustainability strategies are pivotal to long-term performance, establishing sustainability as determinant driver of innovation in both pushing and pulling contexts. Third, and last but not least, in view of culturebound notions, sustainability is to be considered as crosscutting approach to all business matters, and source of creative resilience, known as collaborative cultures for sustainability. Dual challenges of ambiguity and branding need to be embraced as business opportunity overtly attributed to corporate cultural responsibility and driver of success.

In a nutshell, recalling the research questions raised, theory-based insights obtained through literature review lead to the triple arguments that

1) Socio-cultural contexts are increasingly taken into account for corporate sustainability; however, there is little case-related evidence that those might constitute a strategic driving force to corporate sustainability governance;

2) Cultural aspects are related to corporate sustainability through underlying value systems; however, there is hardly any case-related analysis that it might increase the innovative capacity for business-model development;

3) Comparative advantages of sustainability-oriented manufacturing and branding are at hand with corporate sustainability management; however, there is need to elucidate how these practices might favour the identification of business cases for sustainability.

In further replicating these findings with casedistinctive elements there is:

- Little evidence that corporate sustainability is related to the company's brand essence by taking into account brand awareness and recognition;

- Limited embedding of cultural aspects into an integrated corporate strategy for sustainability in fostering business innovation alongside business segments;

- Promising potential for sustainability as corporate matter of business-to-business (b2b) and business-toconsumer (b2c) relations for identifying applicable business cases.

\section{Case description}

The case chosen to convey aspects of corporate sustainability across different socio-cultural contexts is related 
to the fundamentally changing stationery industry, represented by a company with subsidiaries and manufacturing sites across the globe. Based upon theory-bound considerations, analysis exclusively originates from corporate information and insights; combining generic lifecycle analysis or life-cycle assessment (LCA) with corporate-sustainability dimensions serves as structuring element for assessing both qualitative and documented data gathered through methodological triangulation. Several experts' interviews corresponding to this structuralanalytical design constitute the comprehensive context for drawing differentiated conclusions on sustainability performance, opportunity and commitment. In reverse, an implementing concept - subsequently proposed as framework strategy - focuses on the managerial aspects of corporate sustainability by returning analytically processed records to the case-presenting company.

\section{Characteristics}

Quite a number of companies within the business segment are confronted with the dual challenge of both transforming their business models into future-proof concepts and paying tribute to an increase of sustainability awareness among customers simultaneously. Remarkable epitome of this perceived trade-off is the highly fragmented and competitive stationery industry that illustrates the gradual shift from manual writing equipment/devices to digitized text production while avoiding surpluses in paper, ink and packaging consumption (Giarrizzo, 2017; MarketLine, 2013a, p. 12, 2013b, p. 11, 2014, p. 11). Hence, different brands will have to embrace similar challenges simultaneously: "Storage and stationery may also be influenced by switching to a paperless office format. Office services such as photocopying, printing and binding may be substituted by electronic forms of communications" (MarketLine, 2013b, p. 15, 2014, p. 15; Verband der PBS-Markenindustrie im FMI e.V., 2017a). Likewise, many of them do focus on comparable markets and strategic options competing for shrinking market shares, ultimately. However, still of importance, skimming markets might serve as bridging or accompanying option till novel marketing concepts are at place to be implemented reconciling customers' and sustainability needs. Extending the market range globally with aforementioned impetus, cross- and intercultural characteristics need to be accommodated accordingly. This particularly applies in transformational regards, such as customer needs based on trends or strategic commitment towards sustainability (Bleischwitz \& Bringezu, 2011, p. 99; Bretschger, 2011, 11 et seqq.; Roth, 2016, p. 60; Welfens, Perret, \& Erdem, 2011, 28 et seqq.).

The case refers to a listed, globally active company manufacturing writing and marking tools with the recorded sales revenue of roughly EUR 150 Mio. The business volume is generated at global scale through international distribution management companies in around one hundred countries principally served by independent distribution partners unless represented by proprietary sales subsidiaries. Distribution to private and commercial end users is exclusively carried out businessto-business via specialized trading partners, including large-scale sales channels, mail-order companies, and online sales channels as complement to the traditional wholesale and retail trade. Different business activities aligned to value-chain or corporate areas/divisions, respectively, are integrated into an umbrella-like holding structure, including production and distribution subsidiaries in Latin America. The company's self-concept of corporate responsibility comprehends the strategic approach of managing selected aspects of sustainability instigated by a balanced scorecard; a lean-management and corporate-governance approach reflected in a framework of incorporated ISO-certifications and statement of compliance; a corporate willingness to pay more for sustainability-thinking; a vision for novel products that are composed of sustainable qualities, including ecodesign, weight efficiency or innovative materials into product research/development; a critical assessment of supply-chain processes to be optimized in terms of reducing single sources or striving for constantly extending corporate production volumes; a relatively novel flagship brand that constitutes an eco-friendly product line, available at elevated costs compared to the conventional product portfolio; a corporate bias for post-consumer campaigns; a multiplicity of social commitments assumed through earmarked donations as corporate ambassadors; a focus on social, children-centric, mainly educational projects within the portfolio of corporateresponsibility initiatives; and a corporate culture in need of staying responsive and value-based in terms of providing decent working conditions, health and child care, or including corporate events.

Focusing upon corporate sustainability or sustainable entrepreneurship (Schaltegger \& Wagner, 2011, 225 et seqq.; Weidinger et al., 2014), interchangeably, these facets are to be elaborated by means of case study, i.e. examining subject plus contextual conditions, for the following reasons:

- Innovation and business-model development do have a pivotal stake within the company's strategic development, e.g. heading for new product lines (ecoinnovation), providing resourceful services, stretching brands etc. (Machiba, 2011); and

- Cultural contexts do matter in a globally oriented company, e.g. skimming markets, developing culturebound sales and marketing strategies, providing adequate product portfolios etc. 
Based upon the classical business-to-business model of manufacturing and distributing stationery and/or professional office supplies (Schallmo, 2013, pp. 1921 ), on the one hand, the case-representing company is facing challenges of rapidly changing sales and marketing contexts mainly driven through the mega trends (Braun, Loew, \& Clausen, 2008; Presse- und Informationsamt der Bundesregierung, 2011, 14, 18; Stanger, 2017, p. 61) of:

- Digitization refers to the conversion of analogue information of any kind to digital formats with the help of suitable electronic devices. This enables information to be compiled, processed, stored and transmitted through digital circuits, equipment and related networks. Digitalization refers to the process of integrating digital technologies into everyday life that is facilitated by the digitization of everything that can be digitized;

- Commoditization refers to a commercial practice of selling products on the basis of price and not on brand. This co-occurs with reduced margins due to standardized, ever cheaper and more common manufacturing technologies (me-too-strategy and economies of scale) that encourage more suppliers to reduce sales prices even further. Finally, there is a lack of meaningful differentiation in the manufactured goods;

- New market entrants describe emerging players, participants, stakeholders and/or shareholders entering a market or industry sector; and

- Supplier rationalization refers to fundamental changes in supply-chain management that potentially lead to reduced/diminished procurement options due to withdrawal as result of altered market requirements/ conditions, digitization, for instance (Kollmann \& Hensellek, 2016; Kollmann \& Schmidt, 2016, 55 et seqq.; MarketLine, 2014, p. 13; Schallmo et al., 2017; WebFinance Inc. (2019a); WebFinance Inc. (2019b); WebFinance Inc. (2019c); Weinreich, 2016).

Those four drivers gradually question the status-quo business strategy. Thus, a gradual shift towards digitized media and IT business solutions can be observed including sustainability and CSR marketing (Erek, Schmidt, \& Löser, 2013, 155 et seqq.; MarketLine, 2014, p. 13; Mory, 2014; Picot \& Lorenz, 2010; Schram \& Schmidpeter, 2016). Even though accounts on sustainability efforts have increasingly been cumulated, they do not sufficiently reach customers in order to create a significant sustainable move and image on market grounds. Socioculturally diversified markets respond differently to those means, in addition. Hence, a fully-fledged, crosscutting corporate approach - commonly referred to as transformational design alongside the value chain - would actually be required in order to make timely and informed decisions in response to business and market changes (Brooks, Klumpe, \& Puls, 2016, 67, 70; d'Heur, 2014b; Gassmann \& Sutter, 2016; Kollmann \& Hensellek, 2016, 62 et seqq.; Sommer \& Welzer, 2014, 111 et seqq.). The gradual shift of business segments from hardware-related stationery and professional office supplies towards digitized media and IT business solutions addresses sustainability and corporate (social) responsibility as one core competence of related companies in a changing market environment (Altenburger, 2013; Stanger, 2017, p. 61; Zarnekow \& Kolbe, 2013). This implies to either rethink business models from scratch, or gradually develop key segments through business cases of best practice.

On the other hand, changing customer behaviour vis-à-vis sustainability-related needs provides promising prospects of rethinking and revisiting certain strategic business-model assumptions. In that respect, the company is well advised to strive for an intrinsically motivated, integrated concept towards corporate citizenship of sustainability that is based on remarkable corporate responsibility efforts in terms of social and environmental sustainability, above all (Arnold, 2011; GREEN BRANDS Organisation GmbH, 2017; Habisch, Schmidpeter, \& Neureiter, 2008, 15 et seqq.; Schaltegger, 2011a, pp. 188-189; Schaltegger \& Synnestvedt, 2002; Weber, 2015).

\section{Methods}

Case-related research is mainly exploring, including interpreting-inductive elements grounded in contested assumptions and referring to underlying theoretic frameworks and methodological concepts of relevant importance (Gioia, Corley, \& Hamilton, 2013, 17 et seqq.; Jastram, 2012, p. 53; Kromrey, 2002, 58 et seqq.). This implies an inside-out perspective, first and foremost, enabling to reason from existent and collected corporate data to strategy-related considerations in line with corresponding sustainability strategies (d'Heur, 2014a, 30 et seqq.). A twofold approach needs to be taken into account in order to do justice to both cultural-universal and culture-bound options towards corporate sustainability. To this end, all sustainability-related activities of the company and beyond ought to be screened, compiled and analysed in first place, followed by the careful assessment of respective needs and expectations, both universal and culture-bound (Chao et al., 2009, 331 et seqq.; Glauner, 2016; Krause, 2016, 43 et seqq.; Popoli, 2011, p. 420).

Methodological paradigms systematically applied in this context consist of reviewing literature based on principles of qualitative content analysis (Atkinson, 2017, pp. 122-123; Mayring, 2014; Silverman, 2013, 340 
et seqq.) to understand theory-oriented approaches to corporate sustainability, take into account the leading theoretical concepts applied by scholars on selected corporate contexts, and to identify how to adequately embed the intended case study; collecting case-related characteristics to elicit elucidating, confidential up-todate information through a status-quo-analysis of sustainability-related strategic approaches, activities and initiatives, means and instruments, examine underlying corporate perceptions through SWOT-analysis, including business analysis (internal) and environment analysis (external), and to benchmark performance targets and monitoring processes through an analysis of potential or opportunity assessment, respectively; and processing obtained findings in a strategic-directional way to adopt the value-chain-oriented reasoning based upon an extended life-cycle assessment (Frostell, 2013, 842 et seqq.; Gauthier, 2005) as structuring element, apply a multimethod approach of methodological triangulation, relying on stakeholder observation, expert interviews and company resources, and frame case-related characteristics as case study, including data collection, data analysis and data evaluation.

A generic life-cycle analysis or life-cycle assessment (LCA), respectively, represents the core analytic framework, additionally serving as major structuring element. The rationale behind is that an extended life-cycle assessment coincides with corporate value-chain or business segments, including end-of-life aspects. Concepts are often handled interchangeably, neglecting the fact, that there is a meaningful distinction between physical life cycles and market-oriented ones in terms of taking into account competitiveness (Scholz \& Tietje, 2002, pp. 285-304; United Nations Environment Programme, 2012; United Nations Environment Programme (UNEP) \& Delft University of Technology, 2006, p. 80; Wong \& Ellis, 2007, 146 et seqq.). In this context, value chains are regarded as organizational units within companies whereas life cycles are product-related. Through adopting the market-oriented life-cycle perspective, business segments alongside the value chain are considered generically from cradle to cradle, or cradle to grave, respectively. Being fundamentally questioned or not, life-cycle approaches frequently lacked or are still missing strategic management considerations on sustainability (Elkington, 1994, 91, 94; Frostell, 2013, 844 et seqq.; Klöpffer \& Grahl, 2014, 357 et seqq.; Ny \& Robèrt, 2006, p. 61; Ny, MacDonald, Broman, Yamamoto, \& Robèrt, 2006, 63 et seqq.). The viable solution is to come up with lifecycle assessment according to three constituent dimensions of assessing corporate sustainability (see see Fig. 2: Three dimensions of corporate-sustainability assessment (based on and adapted from Balslev Clausen \& Gyimóthy, 2016; Dessein et al., 2015; Gauthier, 2005;
Hansen \& Große-Dunker, 2013, pp. 2409-2411; Hansen, Große-Dunker, Reichwald, \& Ralf, 2009, p. 695; Jørgensen, Le Bocq, Nazarkina, \& Hauschild, 2008; Kagan \& Kirchberg, 2016; Kloepffer, 2008; Krieger, 1972; Maxwell \& van der Vorst, 2003, pp. 892-893; Ny, MacDonald, Broman, Yamamoto, \& Robèrt, 2009, p. 68; Pizzirani et al., 2014; Romeiro Filho, 2015; Stanger, 2017)), including the generic and extended life-cycle dimension of considering supply chain, production, distribution and packaging (logistics), service, use and/or maintenance, and end-of-life; the sustainability dimension through adopting the extended triple-bottom-line principle towards a quadruple-bottom-line of addressing economic, environmental, societal/social aspects of sustainability, adding culture "as a more or less self-standing or freestanding 4th pillar" (Dessein et al., 2015, 24-25, 28, 33; Elkington, 2002, 69 et seqq.; Engert et al., 2016, p. 2834; Jeurissen, 2000, p. 229; Pappas, Pappas, \& Sweeney, 2015, p. 324; Pizzirani et al., 2014, p. 1324; Romeiro Filho, 2015, p. 468; Sonnemann, Gemechu, Remmen, Frydendal, \& Jensen, 2015, p. 11; Weidinger et al., 2014, p. 18); and the corporate-sustainability dimension of assessing:

- Performance: What is the current state of corporate sustainability like?

- Opportunity: Which are key drivers to increase corporate sustainability across socio-cultural contexts? - Commitment: Which feasible conclusions can be proposed?

Methodological triangulation refers to the attempt to improve research validity through combining various techniques. The blend of multiple methods, not to be confused with mixed method, ensures best possible use of different sources of information, and thus generating sound and methodologically-grounded results, pertaining to qualitative research models, in particular (Bohnsack, Marotzki, \& Meuser, 2006; Flick, 2006, 2011; Kuckartz, 2014, p. 19; Lamnek, 2005; Mayring, 2002, 73 et seqq., 2014, p. 8; Scholz \& Tietje, 2002; Silverman, 2013, 199 et seqq., 2014, 22 et seqq.). Within the given context of cross-cultural corporate sustainability, this approach involves the joint recourse to (Prexl, 2010, 301 et seqq.; Puls, 2016):

- Expert interviews: Narrative, first-hand accounts are highly productive sources in case studies for eliciting valuable, directly relevant information for tendencyfinding analysis. Conducted in a semi-structured way, they are evaluated according to principles of qualitative data analysis. Selecting diverse interviewees guarantees holistic insights on the issues, and relies on different experiences and opinions. Hence, interviewed experts 


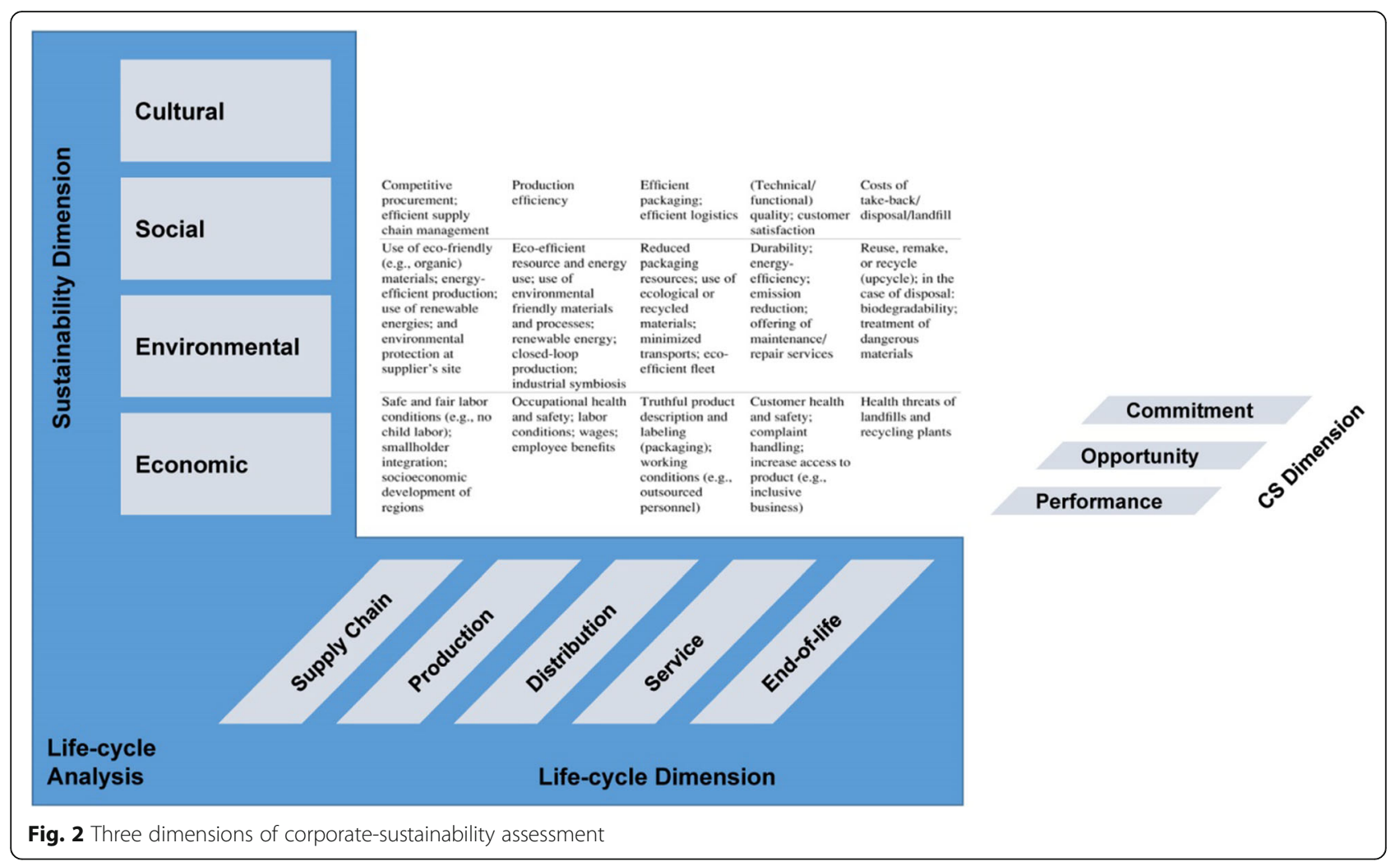

have different, well-defined expertise (Atkinson, 2017, 136 et seqq.; Bogner, Littig, \& Menz, 2014, 13, 15, pp. 17-26; Gläser \& Laudel, 2012, 111 et seqq.; Helfferich, 2011, 55 et seqq.; Kuckartz, 2016, 97 et seqq.; Meffert \& Hensmann, 2014, p. 24); they are not necessarily company officials always, but also independent freelance specialists without any particular institutional affiliation. Envisaged interviewees are company affiliates, i.e. regional representatives and dealers, resource persons from general management, board, corporate responsibility, international sales, marketing and public relations, production; scientific community and market research institutes; and focal groups, i.e. students, professionals, retailers, consumers (Bohnsack, 2007; Cropley, 2005; Deppermann, 2001; Flick, Kardorff, \& Steinke, 2005; Hopf, 2005; Schmidt, 2005a, 2005b; Strati, 2000 ; Strauss, 1998);

- Company resources: Company-related information are pivotal in order to assess contexts accordingly. These include both publicly accessible and confidential documents, personal records and papers which need to be cautiously taken into account. Envisaged documents contain sustainability-relevant and/or strategy-related information (Strati, 2000; Strauss, 1998);

- Stakeholder observation: Stakeholder behaviour and appropriate strategies are examined in both isolation and responsive interaction within varying contexts and situational specifics. Envisaged contexts are related to consumer behaviour, brand-image perception, refill attitude, buying habits, inter alia, and business behaviour, partners, distribution channels, agenda setting, selling/ vending strategies inter alia (Bischoff, Leimgruber, \& Oehme-Jüngling, 2014, 69 et seqq.; Bohnsack et al., 2006; Flick, 2006; Lamnek, 2005; Mayring, 2002).

\section{Data}

The format of embedded case study is applied in order to explore aspects of corporate sustainability in situ, and to draw case-related conclusions about it. Empirical case studies are widely recognised tools of organizational research, in business contexts, above all. Scholars take advantage of explicitly referring to qualitative indicators of performance analysis. Case-study research is most effectively carried out through combining multiple techniques simultaneously (Gioia et al., 2013, p. 16; Jastram, 2012, p. 58; Prexl, 2010, p. 301; Scholz \& Tietje, 2002, 3-4, 9 et seqq., 14, 15 et seqq., 23-25).

\section{Data collection}

Accessing relevant information is prerequisite of being able to properly analyse and assess given research aspects; this particularly applies to obtain internal, often confidential company information. Both research concern and required access to data has been realised in close interplay between academic and corporate entities. In-depth briefings have facilitated the establishing of 
valuable networks of resource persons and experts, both at national and global scale. In compliance with principles of guided interviews, a respective questionnaire has been prepared, focusing on theory-induced facets of corporate sustainability. Strategies of approaching fieldstudy research have been systematic and aligned to the subject matter. Neither insurmountable access denials nor sampling conflicts have occurred during the phase of collecting data. Gathered interview data and physical records have preferably been documented in a digital way, ensuring relevant back-up options. Almost twenty expert interviews had been conducted in three different languages across company subsidiaries in three different socio-cultural contexts/countries; in this respect, questions of multilingualism/translation and intercultural communication have been daily routine and occurrence, even though in well manageable way. Questions have been formulated ad hoc referring to pre-structured questionnaire. No specific interview techniques have been applied of generating dialogue, mainly following the common routine of salutation, reciprocal introduction, question and answer, brief discussion and feedback, follow-up, and leave-taking (Bogner et al., 2014, 27-48, 58 et seqq.; Gläser \& Laudel, 2012, 83 et seqq.; Silverman, 2013, 199 et seqq.).

\section{Data analysis}

Analysing collected data is theory-driven; theorygrounded guidance implies that in all procedural decisions systematic reference is made to the latest research on the particular subject or comparable subject fields, respectively. In terms of qualitative content analysis, related arguments are to be granted priority over procedural arguments. In consequence, validity is of more importance than reliability. The compiled corpus of expert interviews, blacked out for privacy reasons by referring to depersonalized initials, company resources, and stakeholder observations, imparts threefold types of knowledge for analysis: technical knowledge, procedural knowledge and interpretative knowledge. Underpinned by the structuring multi-dimensional corporatesustainability assessment, descriptive elements are complemented by deductive category assignment, ultimately culminating in normative conclusions. Instead of a fullyfledged system of transcription with specific typescripts, a selective protocol is taken as basis for qualitative content analysis. By adopting the reduced procedure for transcription, only those parts of the audio-recorded interviews are defined that are relevant to the research questions. Alternatively, given an open-ended, narrative character of the interview, analysis may easily focus on selected aspects only. Important to note is that clear-cut selection criteria need to be defined in advance, thus, transcription is exclusively led to those relevant passages through these normative markers. In this very context, selection criteria comprise of corporate-sustainability relevance in combination with life-cycle analysis or assessment, and recalled dimensions of sustainability (Bogner et al., 2014, 71 et seqq.; Mayring, 2014, 41, 45, 95-96; Silverman, 2013, 230 et seqq.; see Fig. 2: Three dimensionsof corporate-sustainability assessment (based on and adapted from Balslev Clausen \& Gyimóthy, 2016; Dessein et al., 2015; Gauthier, 2005; Hansen \& GroßeDunker, 2013, pp. 2409-2411; Hansen et al., 2009, p. 695; Jørgensen et al., 2008; Kagan \& Kirchberg, 2016; Kloepffer, 2008; Krieger, 1972; Maxwell \& van der Vorst, 2003, pp. 892-893; Ny et al., 2009, p. 68; Pizzirani et al., 2014; Romeiro Filho, 2015; Stanger, 2017)).

\section{Data evaluation}

Interpreting findings retrieved from qualitative data consequentially follows the algorithms of qualitative content analysis; therefore, for theory-based approaches like this, two consecutive steps are proposed:

1) Structuring content analysis is the grass-root activity of identifying, describing and characterizing topics, categories and their correlations. Available data is systematically scoured and attributed to the related content category against by the pre-structuring theoretical background (questionnaire). Samples illustrate corresponding phenomena in more detail, followed by drawing case-related, content-wise conclusions. Depending on the degree of complexity visualization is suggested to be easily grasped; and

2) Reviewing content analysis is a follow-up technique focusing on both evaluating and assessing content bases. The rationale behind is to rate, and at the same time scale established category concepts within their relational systems. This procedure enables to highlight characteristics that may lead to specific patterns, subsequently determined to provide reasoning, advice, recommendations, guidelines or strategic considerations (Bogner et al., 2014, 71 et seqq.; Kromrey, 2002, 309 et seqq.; Kuckartz, 2016, 97-122, 123-142; Mayring, 2014, 8 et seqq., 2015, 26 et seqq.; Schreier, 2014, pp. 8-9; Silverman, 2013, 304 et seqq.).

\section{Discussion and evaluation}

Given case-related data obtained through methodological triangulation, which results need to be discussed in terms of conveying aspects of corporate sustainability across different socio-cultural contexts? Considering the aforementioned objectives as guideline, three consecutive steps have been suggested to contribute to some kind of framework implementation strategy; these are: 
1) Sustainability performance: Evaluating the current state of corporate sustainability;

2) Sustainability opportunity: Identifying key drivers in order to increase corporate sustainability across socio-cultural contexts; and

3) Sustainability commitment: Proposing feasible/ viable conclusions for implementation.

\section{Sustainability performance}

Carefully taking into account the indications obtained, compiled and deduced from accessible company data, what is status quo of corporate sustainability-related strategic approaches, activities and initiatives, means and instruments like? How can the current state of corporate sustainability ultimately be assessed and classified?

Sustainability performance in this case study is related to a) an extended life-cycle analysis (LCA), and b) the triad of marketing in business-to-business relations, business segments in sustainability contexts, and culturebound/intercultural notions of sustainability. In this context, performance is bound to value-focused thinking rather than to operating figures. Which implies that its assessment is qualitative and individual sui generis; thus, the rationale behind cannot be determined objectively, as result of performance figures, for instance (Ahn \& Hanh Le, 2016, pp. 371-372; Balslev Clausen \& Gyimóthy, 2016; Dessein et al., 2015; Gauthier, 2005; Hansen \& Große-Dunker, 2013, pp. 2409-2411; Jørgensen et al., 2008; Kagan \& Kirchberg, 2016; Kloepffer, 2008; Krieger, 1972; Maxwell \& van der Vorst, 2003, pp. 892893; Pizzirani et al., 2014; Romeiro Filho, 2015). Therefore, the supposed/defined value for assessing sustainability performance is to what extent are aspects of sustainability incorporated within respective corporate management segments, to be specific, supply chain, production, packaging/distribution, service/use, and end-oflife?

The corresponding value-assessing spectrum ranges from full extent (fully applicable) to limited scale (partially applicable) to rudimentary (not applicable) (see Fig. 3: Sample of corporate sustainability performance).

Interpreting the sample qualitative assessment in terms of corporate sustainability performance, it becomes clear that:

1) There are well identifiable aspects of sustainability incorporated alongside the corporate value-chain segments; and

2) There is strategic potential in designated corporate management segments to improve its sustainability performance. To be specific, economic aspects of supply-chain management, and both environmental and social aspects of logistics' management deserve most careful considerations as business segments in sustainability contexts. Culture-bound/intercultural awareness vis-à-vis sustainability is well represented and applied in manufacturing management.

Taking these findings, what might be consequential framing categories of exploring corporate sustainability potential/opportunity? Leading questions are:

- Which role does stakeholder involvement play as to awareness and commitment?

- How do respective marketing contexts of business-tobusiness (b2b) and business-to-consumer (b2c) possibly exert influence?

- How does the value proposition internally correspond to readiness in terms of product portfolio, marketspecific management structures or strategic alignment?

\section{Sustainability opportunity}

Sustainability opportunity is grounded on a) drawing logical conclusions from sustainability performance, particularly with regard to stakeholder involvement/ commitment, marketing contexts, and brand/value proposition; and b) deductively reasoning out strengths, weaknesses, opportunities and threats of corporate sustainability (Fig. 4: Sample SWOTs tocorporate sustainability), including both environment analysis (external) and business analysis (internal) based upon experts' accounts, company resources and stakeholder observation (methodological triangulation).

Given the strategic potential, which are key drivers conducive to increase corporate sustainability across socio-cultural contexts? The objective of providing a differentiated perspective on sustainability opportunity particularly involves the question which and how factors are rendered relevant in a universal or culture-bound way. This may include conceptual approaches for stakeholder mapping and communication.

Assessing potential can be carried out in a qualitative way by taking into account:

- Internal factors, such like specific knowledge, skills and/or abilities available within the company; and resources available to the company, including staff, financial resources and technologies to be acquired for launch and growth of the opportunity; and

- External factors, such like characteristics of the industry sector in terms of key competitors, structure, entry-barriers or pertinent trends that are likely to affect business activities; the market in terms of knowledge of preference, values, buying behaviour, including demographic and psychographic information necessary to appropriately position, promote and price the products and services; social norms, values and trends, including evidence for temporary fashion, increased need 


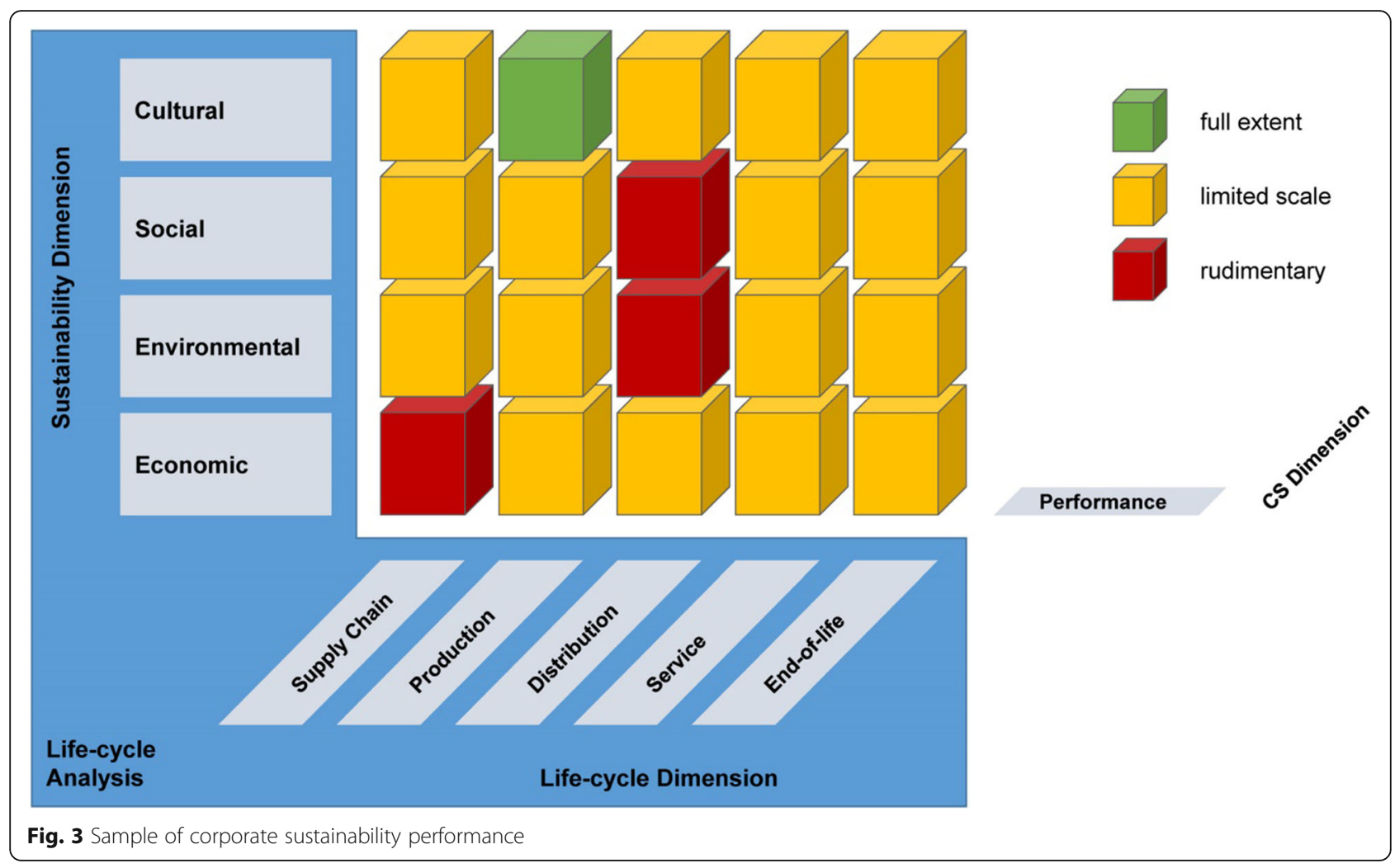

or awareness, ethical concerns about its effects, social environment, and perceptions of the opportunity in the minds of customers and citizens; legal and regulatory forces possibly affecting business operations, including laws, policies, procedures and regulations (Gundry \& Kickul, 2007, p. 65).

Evaluating corporate sustainability potential follows the comprehensible principle of extending strengths and diminishing weaknesses, incorporates internal and external factors, and is directly attributed to the four strategic options. Consequentially, the corresponding opportunityassessing spectrum ranges from questionable (poor prospects equivalent to minimise) to pendant (undetermined equivalent to optionally secure or catch-up) to promising (excellent prospects equivalent to expand) (see see Fig. 5: Sample of corporate sustainability opportunity).

Interpreting the sample qualitative assessment in terms of corporate sustainability opportunity, it can be stated that:

1) There is significant prospect to take further steps towards sustainability alongside the corporate value-chain segments;

2) There are distinguished opportunities in designated corporate management segments to enhance corporate sustainability. Especially supply-chain and end-of-life processes have been identified promising to considerably intensify sustainability-oriented commitment. Both environmental and cultural aspects ought to be listed high on the corporate agenda in order to profit most from expected potentials;

3) There is need to institutionalize stakeholder dialoguing through providing professional stakeholder management that exceeds customerrelationship management;

4) There are cultural aspects to be painstakingly considered/prioritized, according to reports and strategic accounts of progressively shifting and/or extending marketing paradigms from business-tobusiness (b2b) to business-to-consumer (b2c) (Ellson, 2004; Keinert, 2008, 118; 124 et seqq.); and

5) There is opportuneness by adopting sustainability conduct to review the value proposition, particularly in view of product portfolio (streamlining), market-specific management structures (regional autonomy) and strategic alignment (pioneering spirit/image).

Taking these findings, what might be a resulting design of contouring corporate sustainability commitment? Leading questions are:

- What are case-related key drivers to trigger corporate sustainability in general? 


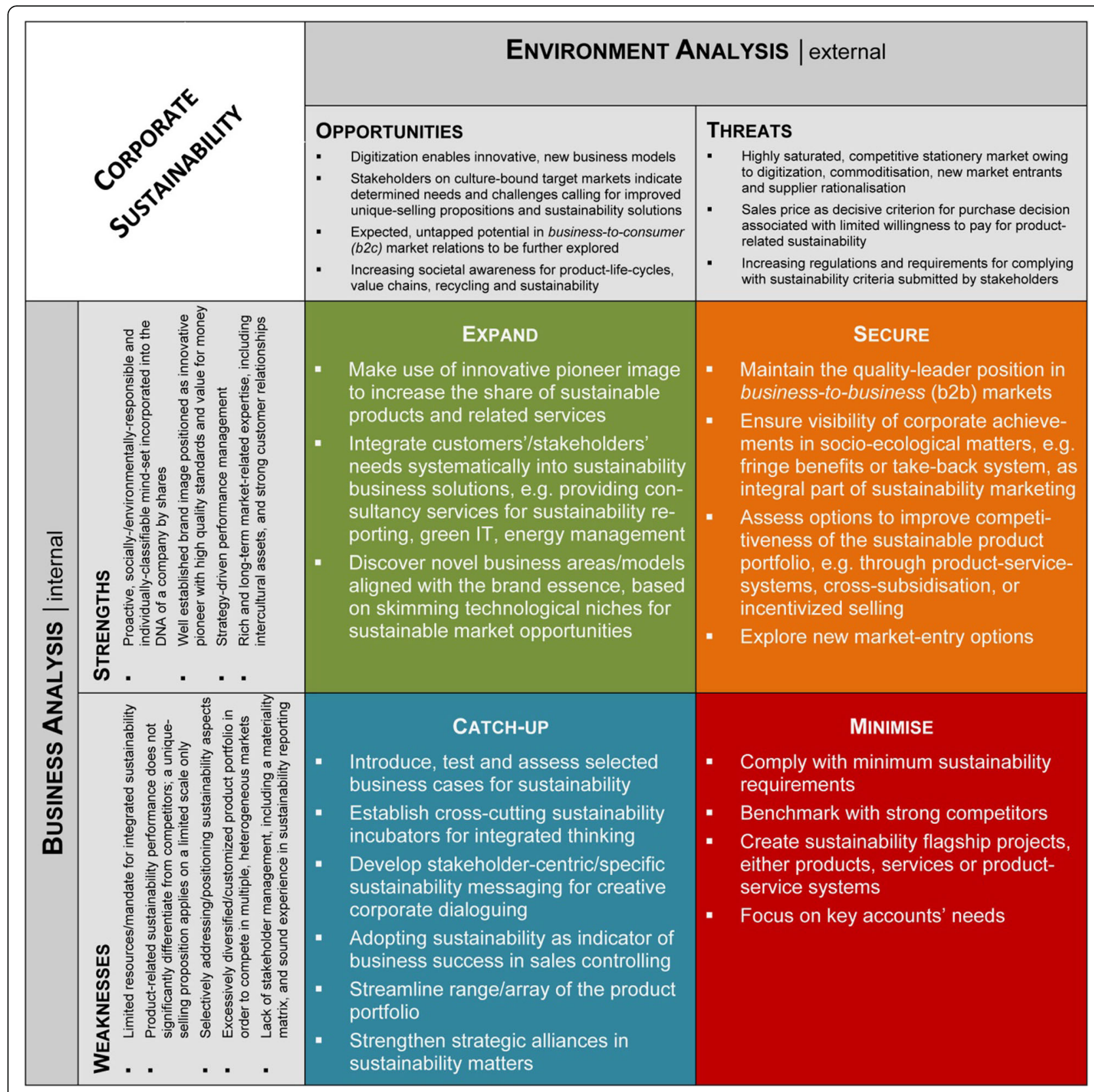

Fig. 4 Sample SWOTs to corporate sustainability

- What are conducive outlines to formulate impactoriented operational guidelines?

\section{Sustainability commitment}

Assessing sustainability commitment comprises a) identifying and explaining key drivers to corporate sustainability (see Fig. 6: Sample corporate drivers to corporate sustainability) deduced from both SWOT-analysis (see Fig. 5: Sample of corporate sustainability opportunity), and experts' accounts, company resources or related stakeholder observation (methodological triangulation); and b) collecting resultant keynotes for corporate commitment to be further defined in operational guidelines (Bhardwaj, 2016; Daneshpour \& Takala, 2016; Graafland \& Smid, 2012; Schaltegger \& Wagner, 2006, p. 2; Smith \& Muller, 2016, 76 et seqq.; Stampfl, 2016, p. 87; United Nations Environment Programme (UNEP) \& Delft University of Technology, 2006, 26 et seqq., pp. 60-61).

Considering the key drivers of selected strategic options, which feasible conclusions can be drawn with sustainability commitment in mind? 


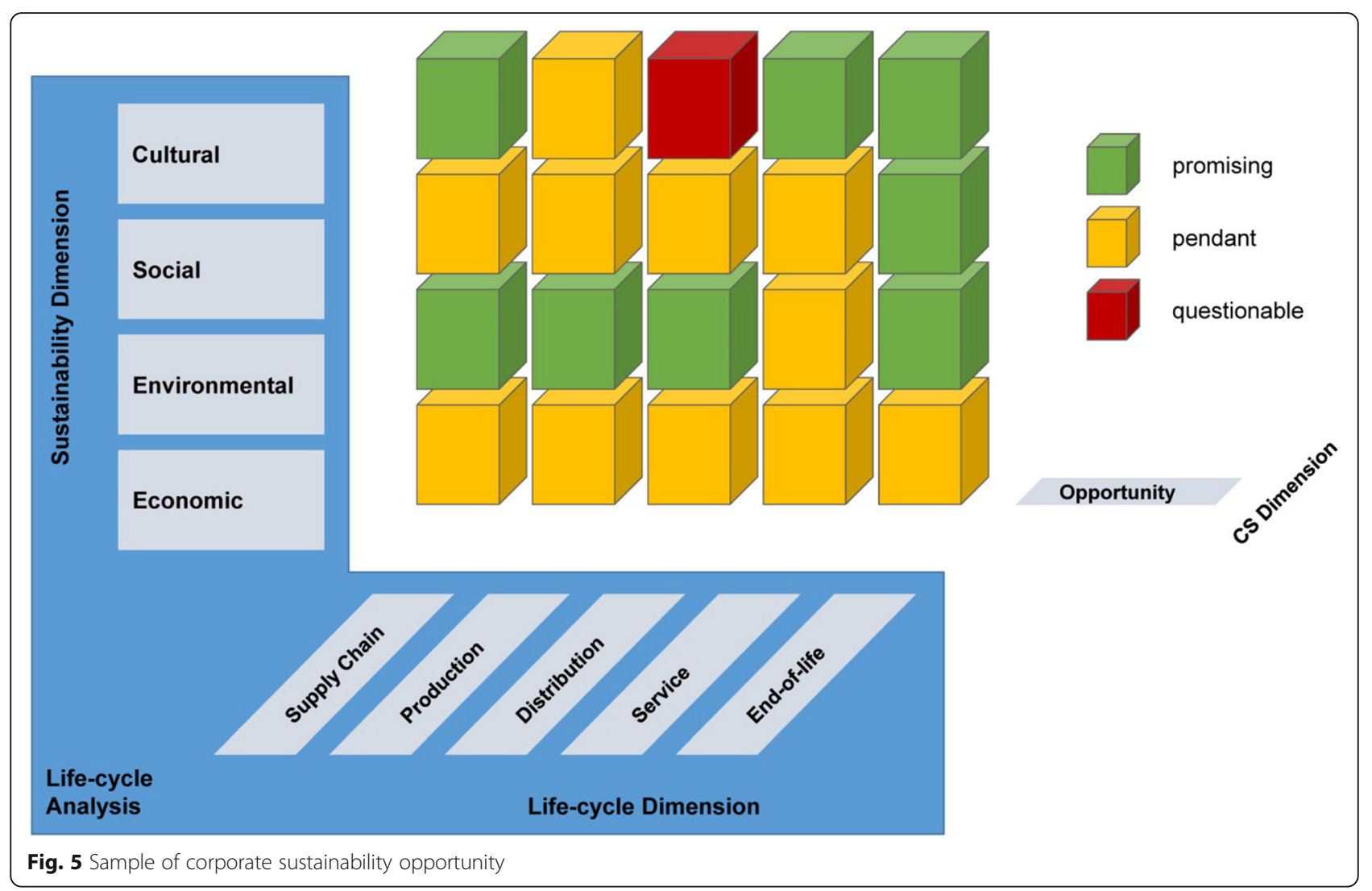

Determining criterion for qualitatively rating corporate commitment is the likelihood for specific future involvement. Three options are proposed to address assessing commitment. First, there are established corporate typology categories distinguishing between institutional stars (highest commitment), corporate citizens and apathetics (lowest commitment). Second, a continuum is argued from personal dedication to constraint commitment. Thirdly, the level of commitment is decisive capturing no commitment, some commitment, and routinized/wellestablished commitment (Ingram, Lee, \& Lucas, 1991, p. 193; Maki, 2012, p. 47; Stanley \& Markman, 1992, 506 et seqq.).

In this specific context evaluating corporate sustainability commitment is rather notional; nevertheless, to limited extent reasoning is feasible given all strategic options deduced from sustainability performance and potential. In this respect, the likelihood for corporate commitment ranges from low (unlikely implementing probability associated with minimise) to indifferent (uncertain implementing probability associated with either secure or catch-up) to high (likely implementing probability associated with expand) (see Fig. 7: Sample of corporate sustainabilitycommitment).
What can be exemplarily reasoned out from qualitatively rating corporate sustainability commitment is that:

1) There are clearly marked/indicated scopes for sustainability-related (non-)involvement, both alongside corporate value-chain segments and corresponding to a sustainability dimension, prior to formulating impact-oriented operational guidelines;

2) Most momentum can be attributed to the economic dimension of sustainability, capable of raising efficiency and/or synergies in supply-chain, logistics' and service affairs; this indication well coincides with a corporations' originary optimization function, and obtains significant acceptance on these grounds;

3) Least momentum in view of steps towards sustainability can be observed in the scope of logistics, possibly for the reason of lost/outsourced managerial control and/or influence on decisiontaking due to third-party-contractual designs;

4) On environmental grounds, manufacturing and end-of-life processes can promisingly liaise in both strategic and issue-driven sustainability perspectives;

5) On cultural grounds, service-oriented and end-oflife aspects need to be concerted in view of sustainability relevance; 


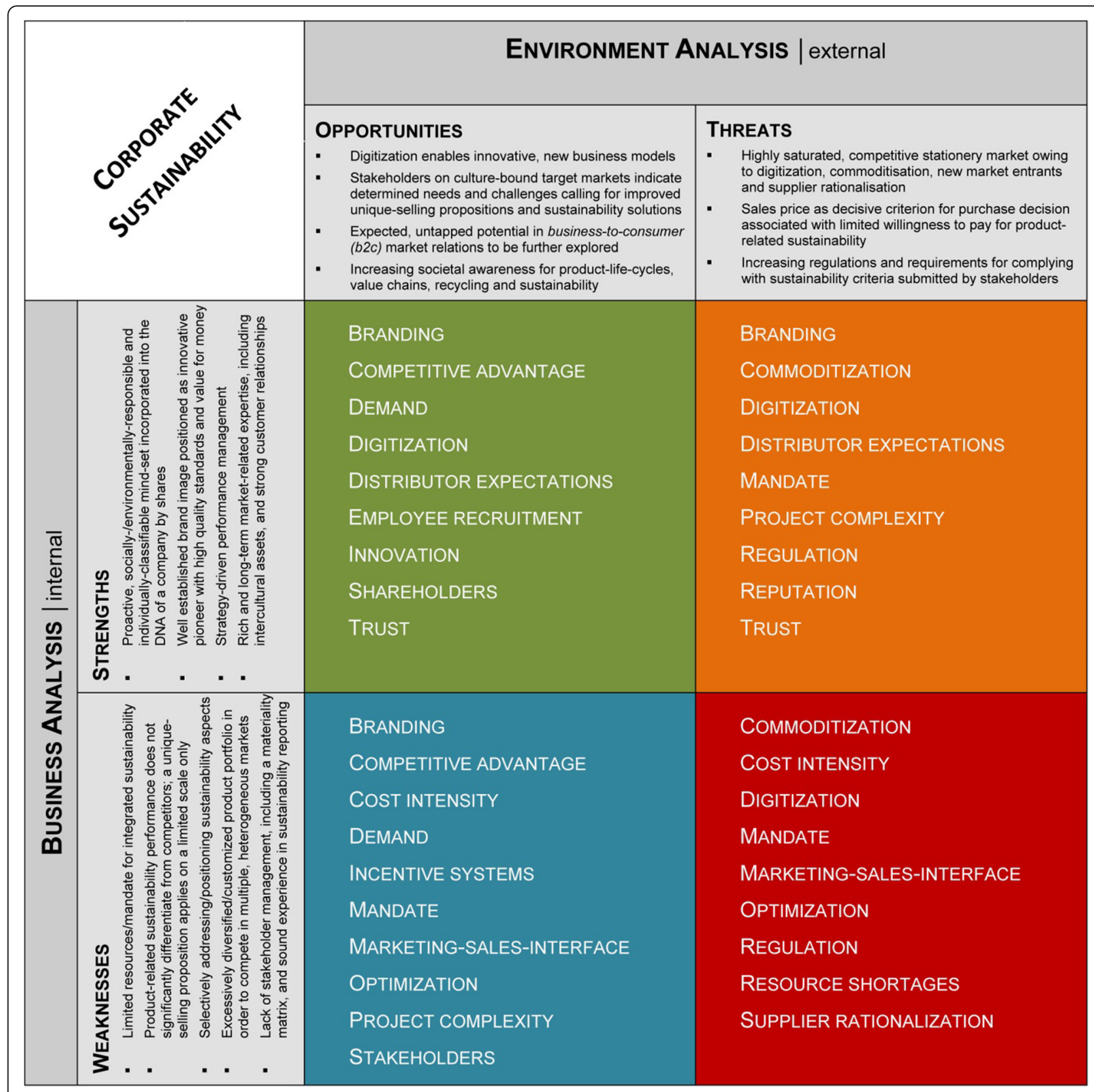

Fig. 6 Sample corporate drivers to corporate sustainability

6) On social grounds, there is reason for well assuming either saturated/satisfyinglyimplemented corporate policies of workplace well-being and generated societal impacts, or context-specific/culture-bound framing conditions that prevent from involvement, in logistics' and end-of-life processes, above all; and

7) Key drivers are identified to trigger corporate sustainability in its diverse strategic setups.
Acknowledging the expected likelihood for sustainabilityoriented, corporate involvement:

- How is sustainability commitment correlated with sustainability performance and sustainability opportunity?

- How can the triad relation of performance, opportunity and commitment be merged into a consistent framework that may provide guidance in terms of implementation? 


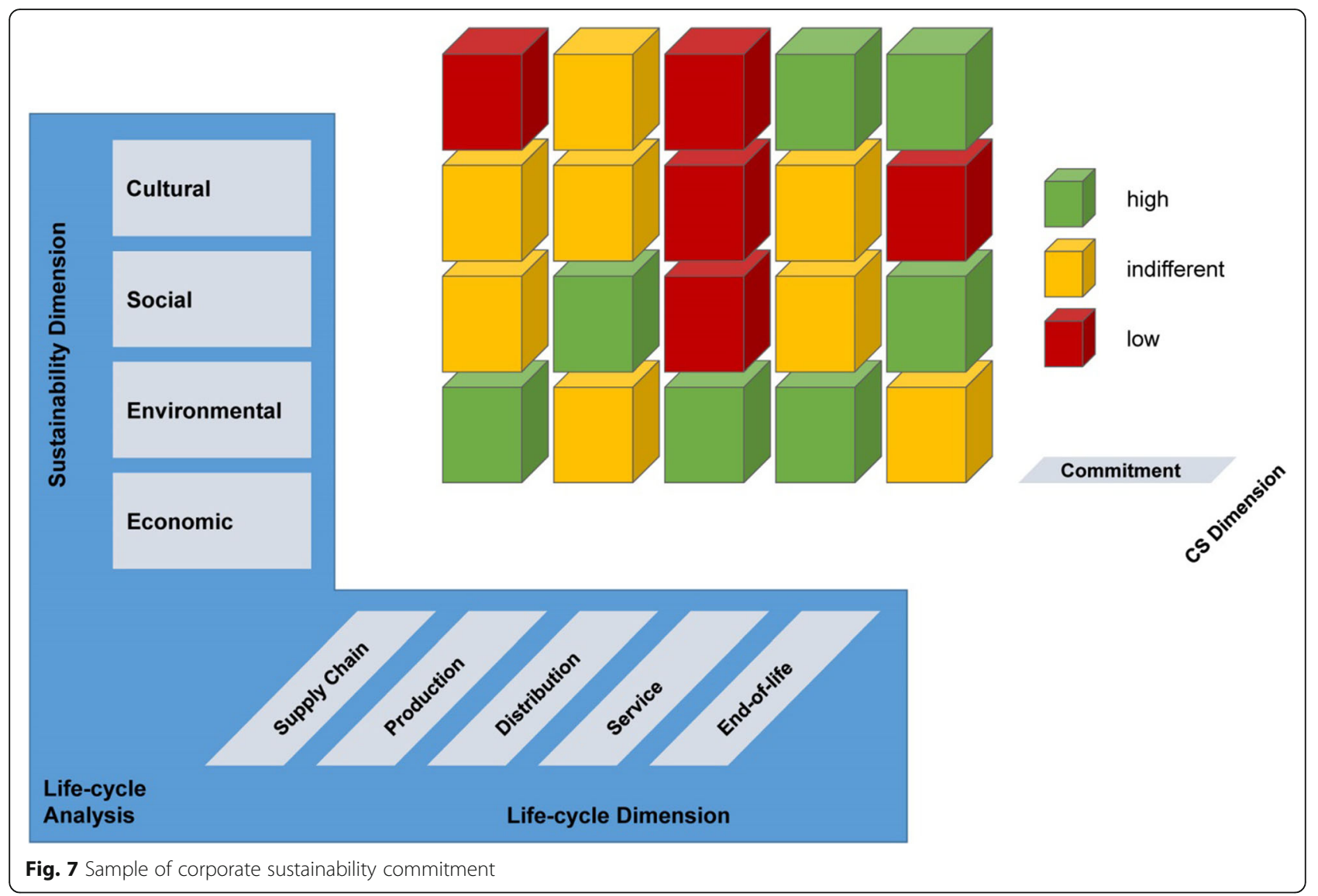

\section{Framework implementation strategy}

Given a dual character of defining strategy by referring to both identifying and assessing present and future comparative advantages and potential for success, and deriving detailed implications for policies and plans of implementation, the framework strategy explicitly focuses on conceptual guidelines for realizing such business opportunity (Morioka \& de Carvalho, 2016; Rusnjak, 2014, pp. 48-50).

The framework-implementation approach to corporate sustainability (Baumgartner \& Rauter, 2017, pp. 82-83) consists of:

1) Elaborating on the underlying or basic/fundamental alignment. Addressing orientation touches upon the overarching principle, the corporate DNA, vision or Why, represented through endurance and rational audacity. To be aware that striving for sustainability with an ulterior purpose beyond purely economic business success, may include refining the corporate value proposition. Combining normative-ethical considerations with the economic rationality of profitability, presumably results in moving/extending strategic corporate targets, beyond provisions of code of conduct, in particular (Viardot, 2017, pp. 1-3); and
2) Accentuating the corporate implementation impetus. Considering prioritized options of operationalization - including reporting, scorecardbalanced accounting and monitoring - draw on strategies to sustainability, the corporate mission or How, thus, affecting business value (Campbell, 2015; Hamilton, 2011, 183 et seqq.; Khalili, 2011b, pp. 152-155; Maletič, Maletič, \& Gomišček, 2012, pp. 220-221; Morioka \& de Carvalho, 2016, 139 et seqq.; Viardot, 2017, 13, 38, 41, 59, 65, 89, 94, 98) through:

- Universal, general or cross-cutting policies, the corporate agenda or What, which correspond to the entire dimensional scope of the generic life cycle and define "an integrated (...) strategy (of universally-valid corporate drivers and key business functions) that does not change in the various countries where the company operates" (Popoli, 2011, p. 419); or

- Culture-bound, regional or de-centralized policies/paths, the corporate context or To what extent, that focus on selected/relevant aspects of both life-cycle and sustainability dimension of related corporate drivers and key business functions. 
How does it translate to the sustainability triad of performance, opportunity and commitment? Four linking strategies can be derived and adopted:

1) Product stewardship: Taking care of and managing manufactured property through an awarenessraising process of controlling and communicating product-related impacts in terms of sustainability performance throughout its entire life cycle. What primarily referred to due diligence and liability of products and services, increasingly extends to the opportunity of purposefully integrating stakeholders' perspectives/claims into business processes and circular product development;

2) Operational efficiency: Striving for an optimal allocation, distribution and use of corporate resources alongside the value-chain segments and the four sustainability dimensions according to the efficiency and effectiveness paradigm. What predominantly referred to minimizing resource usage and waste generation by recycling/upcycling, increasingly applies to social/societal, economic and cultural affairs;

3) Innovative transformation: Improving the corporate performance throughout core- and supportive value-chain segments by moving towards novel sustainable business solutions of generated added value. What originally referred to ecologicallydriven product features, increasingly includes selfcontained product-related services, lean management processes and disruptive business-model evolution; and

4) Adaptive responsiveness: Disposing of the corporate ability and commitment to anticipate socio-cultural changes or challenges through open collaboration, and to instantly provide customized, marketable solutions. What commonly referred to demand-driven or needs-based approaches increasingly evolves into evidence-based modes of social listening and/or cultural selling.

Strategic options for sustainable supply-chain management (see Fig. 8: Sample framework implementation strategy: Supply chain) are product stewardship and/or operational efficiency:

- Universal supply-chain policies consist of global procurement framing an optimized number of suppliers; resource planning; principally applicable code-ofconduct provisions for common understanding, including an obligation to respond and sign; the application of unified corporate procedures and ISO-compliant standards; the establishment of corporate buying centres subject to unified terms and conditions; disclosing standard product lines and product-service systems; and stakeholder dialoguing;

- Culture-bound supply-chain policies consist of procurement autonomy with an independent/originary agenda stipulating freedom of contracting; supplier selection; order volume; budgetary planning; and the establishment of regional procurement alliances/ channels;

- Business value can be generated through quality improvement, cost reduction, liability-risk decrease, legitimacy, reputation/credibility, empowerment, employee satisfaction/motivation, corporate bottomline standards, or competitiveness of suppliers, inter alia;

- Key business functions to be involved are procurement, marketing, operations, legal affairs, and human resources, inter alia;

- Drivers considered conducive are commoditization, competitive advantage, cost intensity, digitization, incentive systems, mandate, optimization, project complexity, regulation, resource shortages, supplier rationalization, and trust.

Strategic options for sustainable production management are product stewardship, operational efficiency and/or innovative transformation:

- Universal production policies consist of pruning the offered product portfolio; exchange aimed at synchronized sustainable management routines; the application of unified corporate procedures and ISObased standards; the adoption of globally-shared employment- and off-the-job-training principles; and international technology transfer;

- Culture-bound production policies consist of manufacturing interfaces of sharing eco-production routines or practices of adaptive craftsmanship; and provided fringe-benefits' programmes,

- Business value can be generated through business growth, innovative products, quality improvement, rejuvenation of product lines, streamlined portfolio, legitimacy, reputation/credibility, corporate bottom-line standards, cost reduction, communication in technology, optimized man-machine interface, or economies of scale, inter alia;

- Key business functions to be involved are procurement, marketing, operations, innovation, human resources, research/development, and corporate strategy, inter alia;

- Drivers considered conducive are branding, commoditization, competitive advantage, cost intensity, digitization, employee recruitment, incentive systems, innovation, optimization, regulation, resource shortages, shareholders, and trust. 


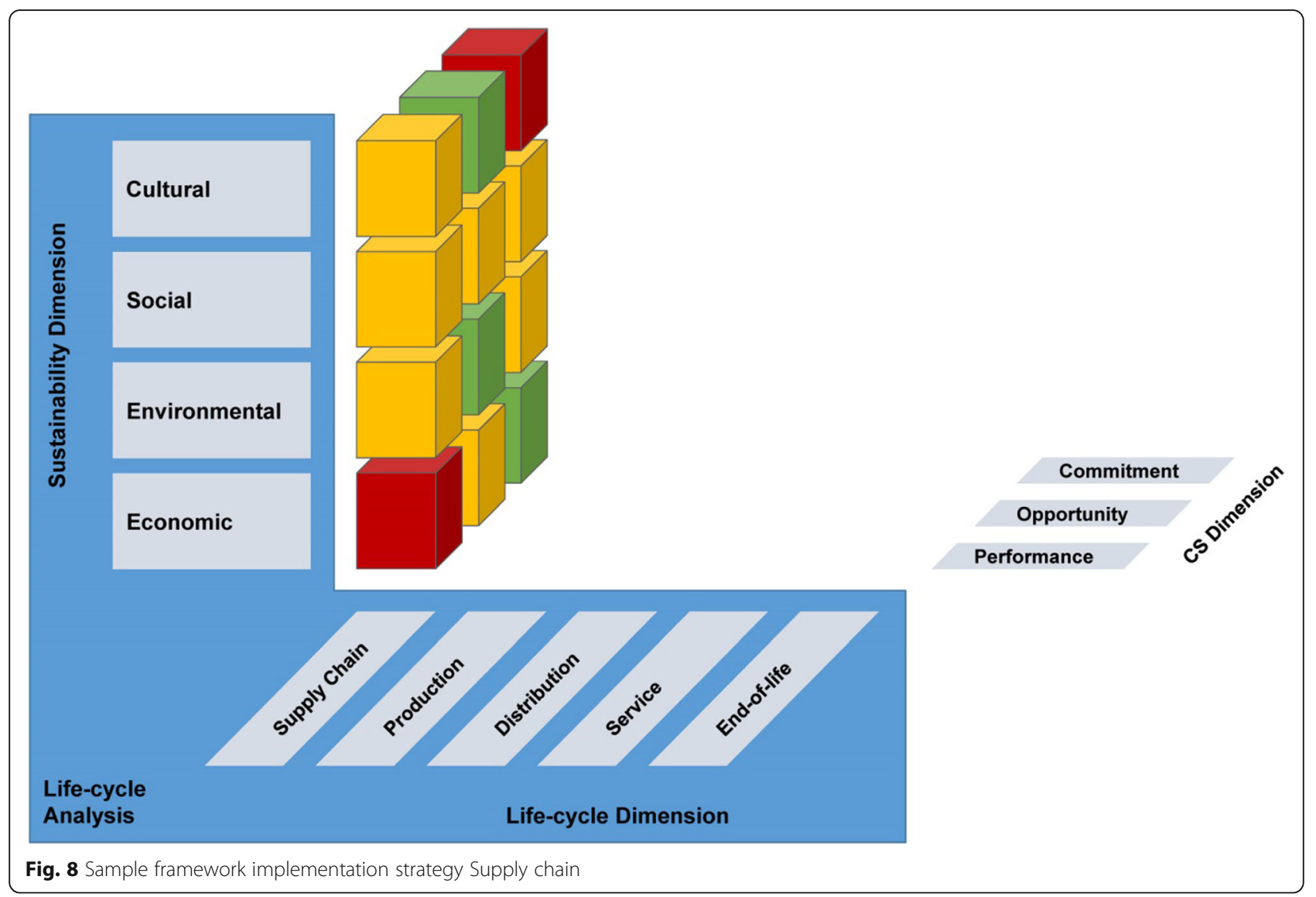

Strategic options for sustainable packaging/distribution management are operational efficiency and/or adaptive responsiveness:

- Universal packaging/distribution policies consist of global logistics framing optimized structures of service providers worldwide; contractual provisions compliant/ equivalent and/or exceeding the code of conduct, including an obligation to respond, sign and report; the application of compatible procedures and universal ISO-compliant standards for integrated accounting/ controlling; and synchronized distribution principles/ routines;

- Culture-bound packaging/distribution policies consist of graded autonomy with regionally differing contractual design ranging from selecting service providers to concluding terms, conditions and distribution volume; and the establishment of regional logistics' alliances/channels;

- Business value can be generated through new markets, streamlined product-service lines, corporate bottom-line standards, cost reduction, reliability, safe business environment, or economies of scale, inter alia; - Key business functions to be involved are operations, human resources, and legal affairs, inter alia;
- Drivers considered conducive are commoditization, competitive advantage, cost intensity, distributor expectations, incentive systems, optimization, and shareholders.

Strategic options for sustainable service/use management are product stewardship, innovative transformation and/or adaptive responsiveness:

- Universal service/use policies consist of consistent compatibility, agility and visibility of the product portfolio; the comprehensive adoption of eco-effective product-service systems, including complementary functionality; streamlined product-related communication; and stakeholder-involving key messaging; - Culture-bound service/use policies consist of advocacy for and dissemination of niche business solutions; and the formation of regional, consumptionoriented stakeholder networks;

- Business value can be generated through product differentiation, new markets, business growth, streamlined product-service lines, reputation/credibility, communication in technology, optimized man-machine interface, innovative products, or quality improvement, inter alia; 
- Key business functions to be involved are operations, research/development, marketing, and corporate strategy, inter alia;

- Drivers considered conducive are branding, competitive advantage, demand, digitization, distributor expectations, innovation, marketing-sales-interface, reputation, shareholders, stakeholders, and trust.

Strategic options for sustainable end-of-life management (see Fig. 9: Sample framework implementationstrategy: End-of-life.) are product stewardship and/or innovative transformation:

- Universal end-of-life policies consist of the amendment of the corporate value proposition; trickle-down brokerage and advocacy; and the plausible embodiment of the dual role of manufacturer and waste-disposal contractor; and the reasoning of value-creation beyond consumption;

- Culture-bound end-of-life policies consist of the adjustment and reconciliation of corporate claims with an in-situ reality of customers' and/or stakeholders' lives; and the co-creation of corporate bonding in diversity; - Business value can be generated through product differentiation, new markets, business growth, streamlined product-service lines, reputation/credibility, innovative products, or quality improvement, inter alia; - Key business functions to be involved are operations, research/development, innovation, marketing, and corporate strategy, inter alia;

- Drivers considered conducive are branding, competitive advantage, demand, incentive systems, innovation, mandate, marketing-sales-interface, regulation, reputation, resource shortages, and stakeholders.

Deducing strategic options to corporate sustainability from the company's vision and mission statement illustrates the promising approach to reconcile sustainability commitment with sustainability performance and sustainability opportunity, since practical reference can instantly be made to the corporate value proposition and corresponding business values. In turn, accessing and/or amending the value system of a company is prerequisite to create implementing momentum. Thus, given the existing sustainability performance, relevant business drivers are identified to enable/facilitate sustainability opportunity that can be expressed in universally or culture-bound measures of a determined policy. Each strategic option may either apply internally or externally, and is more present- or future-oriented, alternatively.

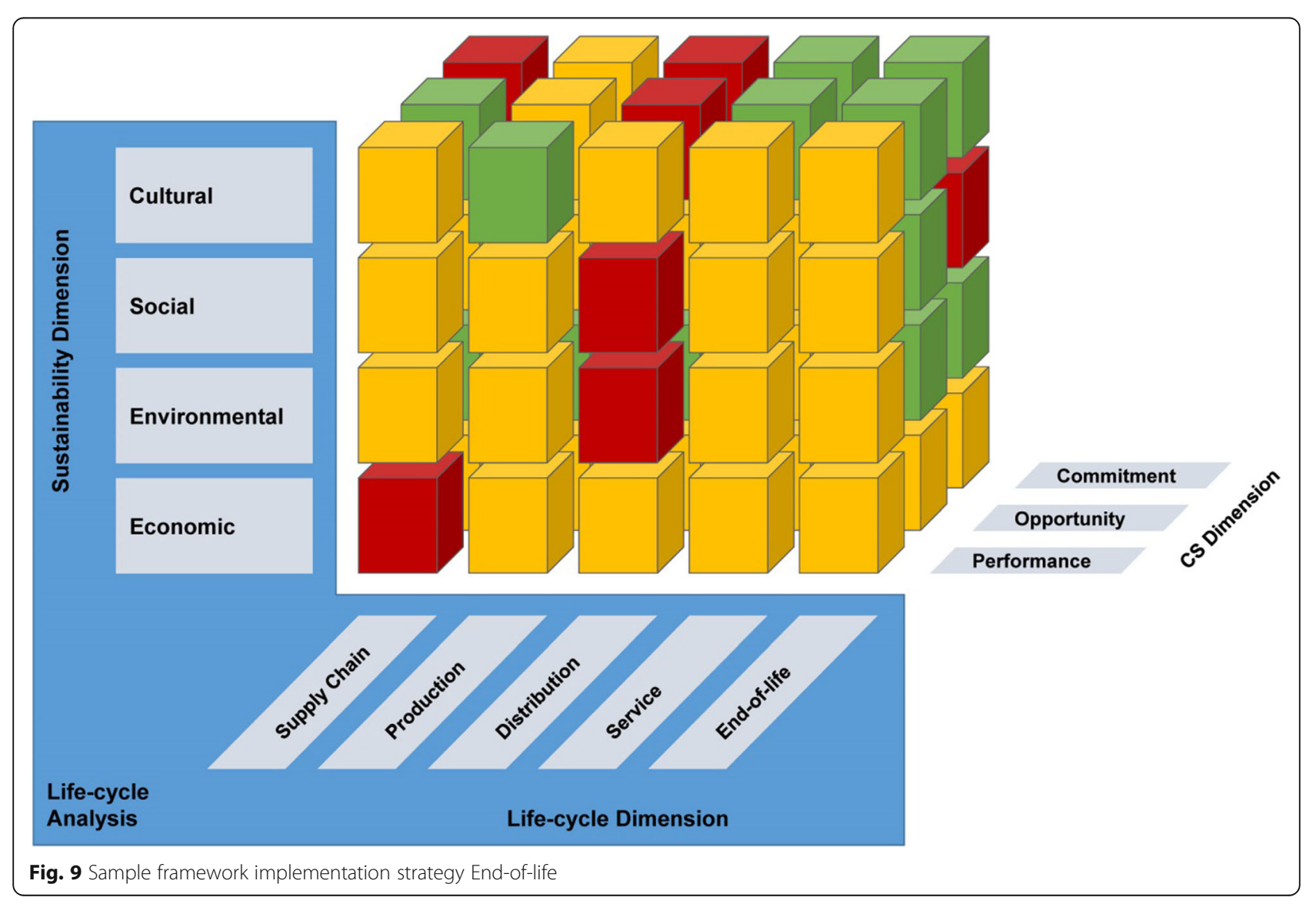


Likewise, corporate key functions/departments contribute to designated business values in direct support of respective strategic alignments (see Fig. 10 Sample framework implementation strategy to corporate sustainability (adapted from Manda, Bosch, \& Worrell, 2015, p. 135)).

Altogether, the analytical proceeding of consecutively considering performance, opportunity and commitment consequently facilitates a consistent framework implementation strategy to corporate sustainability.

\section{Conclusions}

Referring to the proposed framework implementation strategy, which general implications can be stated, and which specific recommendations can be made?

Two major implications arise from the conceptual layout of the diverse implementing options (see Fig. 11: Sample of implementing recommendations to corporate sustainability):

1) Neither the concept of global corporate sustainability nor the notion of corporate citizenship of sustainability, i.e. consisting in integrated efforts of social and environmental sustainability, are comprehensively applicable. Restrictions are primarily subject to the specificities of implementation contexts. Although common patterns of characteristics and drivers suited for framing a coherent theoretical body are identified, corresponding policies are addressed differently at the corporate level. This eventually leads to the effect of disparately contributing to the business-strategy tool of integrated business thinking (Lozano, 2012, pp. 17-18; Rahdari \& Anvary Rostamy, 2015, 763, 767); and

2) Strategic performance management needs to accommodate all dimensional scopes of sustainability. Triggering aspects and issues result from exploring the integration of corporate sustainability into strategic management, thus, enabling sustainability to emerge as integral part of corporate strategic management and business planning. Intentionally advocating for sustainability is the notion of corporate sustainability governance as the new driving force (Engert et al., 2016, 2834, 2838; Fischer, 2017, 151, 210; Krechovská \& Procházková, 2014, p. 1146; Viardot, 2017, p. 7).

Sustainability constitutes an essential element in corporate contexts. Corporate sustainability may be addressed both selectively or integrated. The holistic

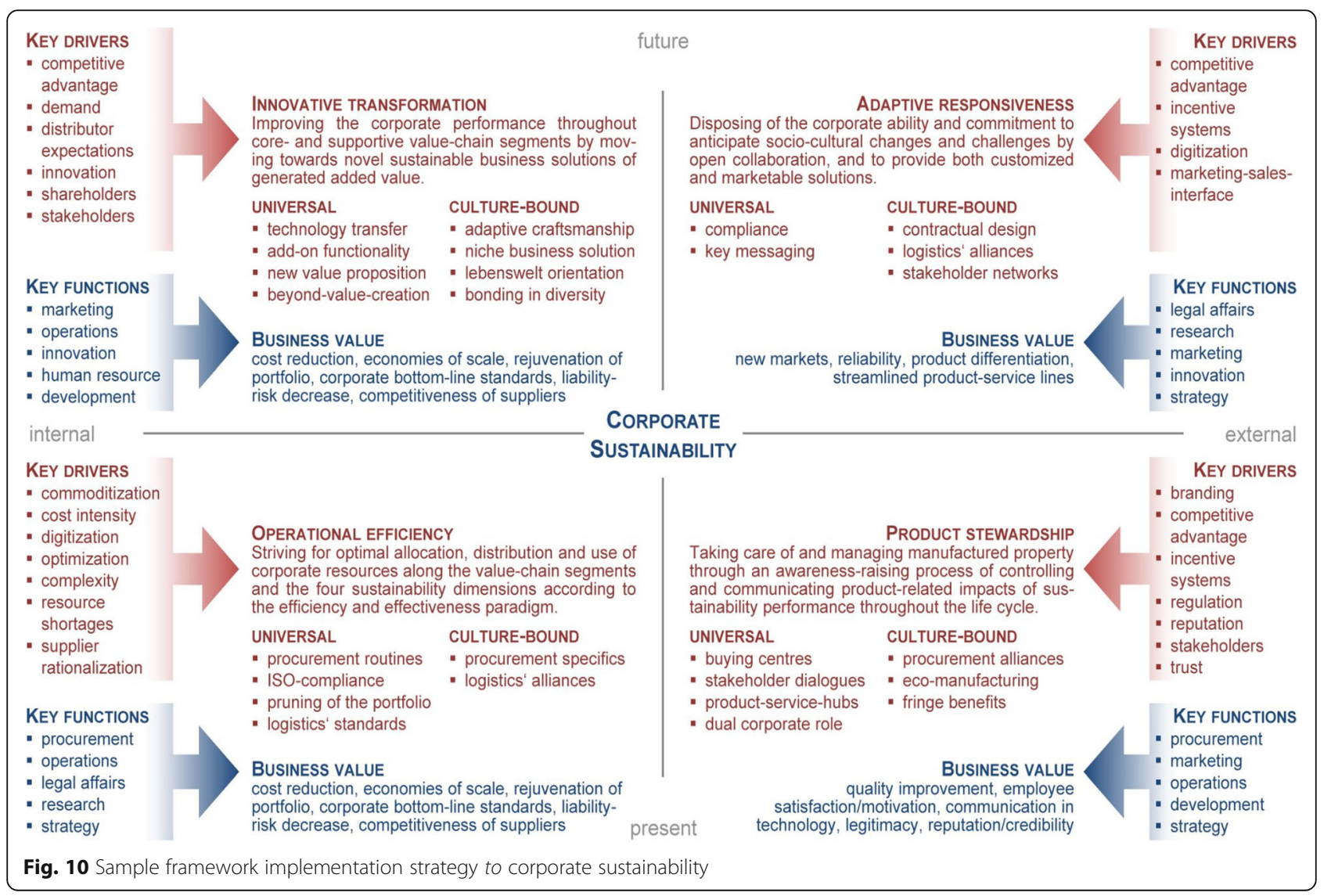




\section{future}

INNOVATIVE TRANSFORMATION

Improving the corporate performance throughout core- and

supportive value-chain segments by moving towards novel

sustainable business solutions of generated added value.

UNIVERSAL

CULTURE-BOUND

- spirit

- alliances

- drivers

- promoters
ADAPTIVE RESPONSIVENESS Disposing of the corporate ability and commitment to anticipate socio-cultural changes and challenges by open collaboration,

UNIVERSAL CULTURE-BOUND

- enhancements - mapping

- adoption visibility

- monitoring

CORPORATE

SUSTAINABILITY

OPERATIONAL EFFICIENCY

Striving for optimal allocation, distribution and use of corporate resources along the value-chain segments and the four sustainability dimensions according to the efficiency and ef fectiveness paradigm

UNIVERSAL

CULTURE-BOUND

- business cases

- interfaces

- governance

- impetus

- conformity

- provision
PRODUCT STEWARDSHIP Taking care of and managing manufactured property communicating product-related impacts of sustainability performance throughout the life cycle

UNIVERSAL

CULTURE-BOUND

- target

- portfolio

- re-use

- testimonials

- add-on

- servicification

- eco-design

- circularity

Fig. 11 Sample of implementing recommendations to corporate sustainability

approach presented here, particularly aimed at conveying aspects of corporate sustainability across different socio-cultural contexts. Undoubtedly, there is such a correlation between corporate and culture-bound sustainability. This nexus has been proven through referring to culture-depending notions of sustainability that constitute strategic driving forces to corporate sustainability by facilitating innovative capacities in business-model development, and identifying promising/viable business cases for sustainability-oriented manufacturing and branding. Culture-bound or intercultural awareness visà-vis sustainability is well represented and applied in manufacturing management. Cultural aspects ought to be listed high on the corporate agenda in order to profit most from arising potentials, e.g. progressively shifting and extending marketing paradigms from business-tobusiness (b2b) to business-to-consumer (b2c). In this way, the full scope of sustainability dimensions could be considered as constituent part of sustainability-oriented corporate governance.

Moreover, there are clear indications of contouring the notional shift from corporate (social) responsibility towards an integrated concept of sustainability that is functionality-based and governance-oriented; thus, focusing on systemic innovations and integrated business solutions of embedding socio-cultural behaviour in order to assume the dual mandate of both manufacturer and waste-disposal contractor. Tentative clues of awareness have been raised among corporate stakeholders alongside the value chain; though, eventually leading to strategic stakeholder management requires extended considerations and further efforts.

The research design has been conducive to include the socio-cultural dimension into the life-cycle structure of analysis. Relying on the triad of expert interviews, company resources and stakeholder observation, it has been clear from the very beginning that assuming a generic, five-part life-cycle assessment represents a stylized or archetypal model of approaching corporate reality. This leads to the necessity of transferring/relating findings to the de-facto value-chain segments found and reflected in the corporate structure, accordingly. Opting for the qualitative approach based upon obtained interview data, findings may well be trend-setting; however, these are not representative or evidence-based in statistical terms. Thus, they are applicable in the specific single-case context, only, and cannot be transferred or extrapolated to differing contexts without further ado. General implications and recommendations, in particular, need to be adapted to specific corporate contexts. Resulting charts are rather case-related than theory-induced.

In order to systematically analyse corporate sustainability, the three-part structure of sustainability performance, sustainability opportunity and sustainability commitment made it possible to first, assess the status quo of corporate sustainability-related strategic approaches, activities and 
initiatives, and means and instruments, second, identify universal and culture-bound drivers corresponding to industry-sector-specific characteristics of transformational design in view of relevant mega trends; and, and third, deduce operational guidelines in view of stakeholder awareness, selected strategic options, projects and best practices. Every single sustainability dimension, i.e. environmental, societal, economic and cultural, was studied individually, then correlated with the generic life-cycle category, i.e. supply chain, production, distribution/packaging, service/use, and end-of-life, and finally included into the three-step assessment.

At the core of the resulting framework implementation strategy, there are four detached strategic options, i.e. product stewardship, operational efficiency, innovative transformation, and adaptive responsiveness, ranging from internal/external to present/future. Therein, meaningful cross-sectoral aspects of innovation, businessmodel evolution and predominantly socio-cultural contexts are dealt with accordingly.

To conclude, while recalling and responding to the initially raised research questions:

1) Yes, taking socio-cultural contexts into consideration adequately may constitute a strategic driving force and influential pull factor with regard to corporate sustainability.

Sustainability performance proves that engaging with socio-cultural contexts is particularly conducive in corporate manufacturing management, for instance. Neglecting or rudimentarily paying tribute to cultural conditions limits the sustainability opportunity, since corresponding drivers cannot appropriately be identified. According to examined strengths, weaknesses, opportunities and threats, socio-cultural patterns are tremendously relevant in end-of-life scenarios of productrelated (eco-cultural) resilience.

2) Yes, strengthening cultural aspects of corporate sustainability may definitively increase the innovative capacity for business-model evolution, however rather as push than pull factor.

The framework implementation strategy integrates compelling culture-bound policies suited for fostering operational efficiency and innovative transformation. Cultural practices become predominantly thrilling in disruptive innovation processes or readjustments of business models which exceeds purely culture-related design and branding options by far.

3) Yes, highlighting comparative advantages of sustainability-oriented manufacturing and culture- specific branding as push factor favours the identification of business cases for sustainability.

Corporate drivers to corporate sustainability incorporated into the framework implementation strategy substantiate culture-bound policies to encourage adaptive responsiveness through a) anticipating socio-cultural trends in a barometer-like mode and b) detecting promising elements of sustainability-oriented business cases, e.g. in view of function-driven product-service systems, cross-cultural production/manufacturing routines or policies of logistics.

Corporate commitment to/for sustainability is particularly advised in challenging times of economic turbulence and rapid changes; it represents the window of opportunity to revisit assumptions and value propositions of long-lived business models (Prexl, 2010, p. 128). In a nutshell, it is high noon to tackle integrated business solutions and gradually turning them into fully-fledged business models through kicking off with developing and launching business cases for/to sustainability which apply across strategies and cultures!

\section{Abbreviations \\ b2b: Business-to-business; b2c: Business-to-consumer; CC: Corporate citizenship; CR: Corporate responsibility; CRM: Customer-relationship- management; CS: Corporate sustainability; CSR: Corporate social responsibility; LCA: Life-cycle analysis/assessment; SWOT: Strengths, weaknesses, opportunities and threats; USP: Unique-selling-proposition}

\section{Acknowledgements}

Not applicable.

Authors' contributions

Authorship is exclusively owned by MG. The author read and approved the final manuscript.

\section{Authors' information}

Having completed studies in economics, intercultural communication, Martin Gerner received his PhD in international relations for interdisciplinary research into education for sustainable development. Holding an MBA in sustainability management he has been consecrating himself to both selected aspects of corporate sustainability and topics alluding to cultural sustainability.

For contact: martin.gerner@tu-dresden.de

\section{Funding}

Funding was partially applied by the case-study-related company for providing the overall research infrastructure, including office access/use, interviewee selection, accommodation/travel expenses and research scholarship funds; funding, however, did not exert any influence on the design of the case study, collection, analysis and interpretation of data, and in writing the manuscript.

\section{Availability of data and materials}

The datasets generated and/or analysed during the current study are not publicly available due to a corporate confidentiality clause for publication and duplication without expressed third-party consent/permission of both author and company; however, further/specific information are available from the corresponding author (MG) on reasonable request. 


\section{Competing interests}

The author declares that he has no competing interests.

Received: 28 November 2018 Accepted: 30 May 2019 Published online: 28 June 2019

\section{References}

Acosta, A. (2013). El buen vivir: Sumak Kawsay, una oportunidad para imaginar otro mundo. Antrazyt: Vol. 387. Barcelona: Icaria.

Adams, R., Jeanrenaud, S., Bessant, J., Overy, P., \& Denyer, D. Innovating for sustainability: A systematic review of the body of knowledge. (2012) Retrieved from http://nbs.net/wp-content/uploads/NBS-Systematic-ReviewInnovation.pdf.

Ahn, H., \& Hanh Le, M. (2016). Decision-oriented performance measurement framework - An emphasis on rationality. In H. Ahn, M. Clermont, \& R. Souren (Eds.), SpringerLink: Bücher. Nachhaltiges Entscheiden. Beiträge zum multiperspektivischen Performancemanagement von Wertschöpfungsprozessen (1st ed., pp. 369-383). Wiesbaden: Springer Gabler.

Ahrend, K.M. (2016). Geschäftsmodell Nachhaltigkeit: Ökologische und soziale Innovationen als unternehmerische Chance. Berlin: Springer Science and Business Media; Springer Gabler.

Albers, K., Canepa, P., \& Miller, J. (2008). Analyzing the environmental impacts of simple shoes: A life cycle assessment of the supply chain and evaluation of endof-life management options. Santa Barbara: Retrieved from University of Santa Barbara, California website http://www.bren.ucsb.edu/research/documents/ SimpleShoesFinalReport.pdf.

Albers, S., \& Krafft, M. (2013). Vertriebsmanagement: Organisation - planung controlling - support. Lehrbuch. Wiesbaden: Springer Gabler.

Allen, M. (2016). In S. O. Idowu \& R. Schmidpeter (Eds.), Strategic communication for sustainable organizations: Theory and practice. Cham: Springer.

Allen, M. W., \& Craig, C. A. (2016). Rethinking corporate social responsibility in the age of climate change: A communication perspective. International Journal of Corporate Social Responsibility, 1(1), 249. https://doi.org/10.1186/s40991-016-0002-8.

Altenburger, R. (Ed.). (2013). Management-Reihe corporate social responsibility. CSR und Innovationsmanagement: Gesellschaftliche Verantwortung als Innovationstreiber und Wettbewerbsvorteil. Berlin: Springer Gabler.

Amini, M., \& Bienstock, C. C. (2014). Corporate sustainability: An integrative definition and framework to evaluate corporate practice and guide academic research. Journal of Cleaner Production, 76, 12-19. https://doi.org/10.1016/j. jclepro.2014.02.016

Anbari, F. T., Khilkhanova, E. V., Romanova, M. V., \& Umpleby, S. A. (2010). Managing cross cultural differences in projects (pp. 1-12) Retrieved from http://www.unice.fr/crookall-cours/iup_cult/_docs/_Anbari\%202009\%20CrossCultural\%20project\%20management.pdf.

Aquilon, M. (1997). Cultural dimensions in logistics management: A case study from the European automotive industry. Supply Chain Management: An International Journal, 2(2), 76-87. https://doi.org/10.1108/13598549710166122.

Archer, D., \& Cameron, A. (2009a). Collaborative leadership: How to succeed in an interconnected world. Oxford: Butterworth-Heinemann.

Archer, D., \& Cameron, A. (2009b). Collaborative leadership: How to succeed in an interconnected world. Amsterdam, London: Butterworth-Heinemann.

Arizpe, L. (2015). Culture, diversity and heritage: Major studies. SpringerBriefs on pioneers in science and practice: Vol. 12. Cham: Springer International Publishing.

Arnold, M. G. (2011). The role of open innovation in strengthening corporate responsibility. International Journal of Sustainable Economy, 3(3), 361-379. https://doi.org/10.1504/JSE.2011.041111.

Asif, M., Searcy, C., Zutshi, A., \& Fisscher, O. A. M. (2013). An integrated management systems approach to corporate social responsibility. Journal of Cleaner Production, 56, 7-17. https://doi.org/10.1016/j.jclepro.2011.10.034.

Atkinson, C. (2017). Assessing the relationship between corporate environmental reporting and the embedding of corporate social responsibility in organisations. Sydney: University of Technology Sydney, Ed.

Ayman, R., \& Hartman, E. L. (2011). Laying the foundation: Creating a sustainable culture and shift in business paradigms. In N. R. Khalili (Ed.), Practical sustainability. From grounded theory to emerging strategies (pp. 57-77). Basingstoke: Palgrave Macmillan.

Baan, P., \& Homburg, R. (2013). Information productivity: An introduction to enterprise information management. In P. Baan (Ed.), Management for professionals: Vol. 2. Enterprise information management. When information becomes inspiration (pp. 1-42). New York: Springer.
Backhaus, K. (Ed.). (2015). SpringerLink: Bücher. Handbuch Business-to-BusinessMarketing: Grundlagen, Geschäftsmodelle, Instrumente des Industriegütermarketing (2., vollst. überarb. Aufl.). Wiesbaden: Gabler.

Backhaus, K., \& Muehlfeld, K. (2015). Geschäftstypen im Industriegütermarketing. In K. Backhaus (Ed.), SpringerLink: Bücher. Handbuch Business-to-BusinessMarketing. Grundlagen, Geschäftsmodelle, Instrumente des Industriegütermarketing (2nd ed., pp. 93-120). Wiesbaden: Gabler.

Backhaus, K., \& Voeth, M. (2015). Besonderheiten des Industriegütermarketing. In K. Backhaus (Ed.), SpringerLink: Bücher. Handbuch Business-to-BusinessMarketing. Grundlagen, Geschäftsmodelle, Instrumente des Industriegütermarketing (2nd ed., pp. 17-29). Wiesbaden: Gabler.

Balslev Clausen, H., \& Gyimóthy, S. (2016). Seizing community participation in sustainable development: Pueblos Mágicos of Mexico. Journal of Cleaner Production, 111, 318-326. https://doi.org/10.1016/j.jclepro.2015.01.084.

Bansal, P., \& Song, H.-C. (2017). Similar but not the same: Differentiating corporate sustainability from corporate responsibility. Academy of Management Annals, 11(1), 105-149. https://doi.org/10.5465/annals.2015.0095.

Barmeyer, C. (2009). Kulturvergleich und Interkulturalität: Bilder und Bedeutungen. Lehrstuhl für Interkulturelle Kommunikation. Passau: Passauer Medieninitiative.

Barquet, A. P. B., Cunha, V. P., Oliveira, M. G., \& Rozenfeld, H. (2012). Business models for product-service systems (PSS): An exploratory study in a machine tool manufacturer. In G. Seliger (Ed.), Sustainable production, life cycle engineering and management. Sustainable manufacturing. Shaping global value creation (1st ed., pp. 189-194). Berlin: Springer Berlin.

Bartlett, C. A., \& Ghosbal, S. (1987). Managing across borders: New organizational responses. Sloan Management Review, 29(1), 43-53. https://doi.org/10.2307/ 258620.

Bartlett, C. A., \& Ghoshal, S. (2008). Managing across borders: The transnational solution (2nd ed.). Boston: Harvard Business School Press.

Bauer, T., Brissaud, D., \& Zwolinski, P. (2017). Design for high added-value end-oflife strategies. In R. Stark, G. Seliger, \& J. Bonvoisin (Eds.), Sustainable production, life cycle engineering and management. Sustainable manufacturing (pp. 113-128). Cham: Springer International Publishing.

Baumgarth, C. (Ed.). (2010a). B-to-B-Markenführung: Grundlagen - Konzepte - Best practice (1. Aufl.). Wiesbaden: Gabler.

Baumgarth, C. (2010b). Status quo und Besonderheiten der B-to-BMarkenführung. In C. Baumgarth (Ed.), B-to-B-Markenführung. Grundlagen Konzepte - Best practice (1st ed., pp. 37-62). Wiesbaden: Gabler.

Baumgarth, C. (2014). Markenpolitik: Markentheorien, Markenwirkungen, Markenführung, Markencontrolling, Markenkontexte (4., überarb. u. erw. Aufl. 2014). SpringerLink: Bücher. Wiesbaden: Gabler.

Baumgarth, C., \& Binckebanck, L. (2010). Sales force impact on B-to-B brand equity: Conceptual framework and empirical test. Journal of Product \& Brand Management, 2010(07), 487-498. https://doi.org/10.1108/ 10610421111166630.

Baumgartner, R. J. (2004). Sustainability assessment: Einsatz der Fuzzy Logic zur integrierten ökologischen und ökonomischen Bewertung von Dienstleistungen, Produkten und Technologien. Techno-ökonomische Forschung und Praxis. Wiesbaden: Deutscher Universitätsverlag.

Baumgartner, R. J., \& Rauter, R. (2017). Strategic perspectives of corporate sustainability management to develop a sustainable organization. Journal of Cleaner Production, 140, 81-92. https://doi.org/10.1016/j. jclepro.2016.04.146.

Belz, C. (2010). Markenführung für komplexe B-to-B-Unternehmen. In C. Baumgarth (Ed.), B-to-B-Markenführung. Grundlagen - Konzepte - Best practice (1st ed., pp. 63-78). Wiesbaden: Gabler.

Berndt, J. C. (2016). Brand new: Was starke Marken heute wirklich brauchen (3. Auflage). München: Redline Verlag.

Berndt, J. C., \& Henkel, S. (2016). Benchmarken: Wie Unternehmen mit der Kraft der Marke ganz nach vorne kommen - und die anderen auf Abstand halten (1. Auflage). München: Printamazing.

Berning, A., \& Venter, C. (2015). Sustainable supply chain engagement in a retail environment. Sustainability, 7(5), 6246-6263. https://doi.org/10.3390/ su7056246.

Maurice Berns, Andrew Townend, Zayna Khayat, Balu Balagopal, Martin Reeves. (2009). The business of sustainability: Imperatives, advantages, and actions. BCG Report.

Beschorner, T. (Ed.). (2006). Schriftenreihe für Wirtschafts- und Unternehmensethik: Vol. 15. Unternehmerische Verantwortung in Zeiten kulturellen Wandels (1. Aufl.). München: Hampp. 
Beschorner, T. (2012). What is corporate social responsibility (CSR)? St. Gallen: http://www.zense.ch/. Retrieved from https:/www.youtube.com/watch?v= EONkGtNU_9w.

Bey, N. (2018). Life cycle management. In M. Z. Hauschild, R. K. Rosenbaum, \& S. I. Olsen (Eds.), Life cycle assessment. Theory and practice (pp. 519-544). Cham: Springer International Publishing.

Bhardwaj, B. R. (2016). Role of green policy on sustainable supply chain management. Benchmarking: An International Journal, 23(2), 456-468. https:// doi.org/10.1108/BJJ-08-2013-0077.

Binckebanck, L. (2013). Grundlagen zum strategischen Vertriebsmanagement. In L. Binckebanck, A.-K. Hölter, \& A. Tiffert (Eds.), Führung von Vertriebsorganisationen. Strategie - Koordination - Umsetzung (pp. 3-36). Wiesbaden: Springer Fachmedien Wiesbaden.

Birkeland, I., Burton, R., Novoa, C. P., \& Siivonen, K. (Eds.). (2017). Routledge studies in culture and sustainable development. Cultural sustainability and the nature-culture interface: Livelihoods, policies, and methodologies. Abingdon, New York: Routledge.

Bischoff, C., Leimgruber, W., \& Oehme-Jüngling, K. (2014). Methoden der Kulturanthropologie. Bern: Haupt/UTB.

Bleischwitz, R., \& Bringezu, S. (2011). The resources of economies and the productivity of materials: Relevance, measurement, empirical trends, innovation, resource policies. In R. Bleischwitz, P. J. J. Welfens, \& Z. Zhang (Eds.), International economics of resource efficiency (pp. 89-110). Heidelberg: Physica-Verlag HD.

Bogner, A., Littig, B., \& Menz, W. (2014). Interviews mit Experten: Eine praxisorientierte Einführung. Lehrbuch. Wiesbaden: Springer VS

Bohnsack, R. (2007). Rekonstruktive Sozialforschung: Einführung in qualitative Methoden (6. durchgesehene und aktualisierte Auflage). UTB Erziehungswissenschaft Sozialwissenschaft: Vol. 8242. Opladen: Verlag Barbara Budrich.

Bohnsack, R., Marotzki, W., \& Meuser, M. (Eds.). (2006). UTB Erziehungswissenschaft Sozialwissenschaft: Vol. 8226. Hauptbegriffe qualitativer Sozialforschung (2. Auflage). Opladen: Budrich.

Bouchery, Y., Corbett, C. J., Fransoo, J. C., \& Tan, T. (Eds.). (2017). Springer series in supply chain management: Volume 4. Sustainable supply chains: A researchbased textbook on operations and strategy. Cham: Springer.

Braun, S., Loew, T., \& Clausen, J. (2008). Megatrends der Nachhaltigkeit Unternehmensstrategie neu denken. Berlin: Bundesministerium für Umwelt, Naturschutz und Reaktorsicherheit (BMU).

Bretschger, L. (2011). Sustainability economics, resource efficiency, and the green new deal. In R. Bleischwitz, P. J. J. Welfens, \& Z. Zhang (Eds.), International economics of resource efficiency (pp. 3-18). Heidelberg: Physica-Verlag HD.

Bretzke, W.-R. (2014). Nachhaltige Logistik: Zukunftsfähige Netzwerk- und Prozessmodelle (3. Aufl. 2014). SpringerLink: Bücher. Berlin: Springer Berlin Heidelberg.

Bretzke, W.-R., \& Barkawi, K. (2010). Nachhaltige Logistik: Antworten auf eine globale Herausforderung. Berlin: Springer Berlin Heidelberg.

Brocchi, D. (2016). Nachhaltigkeit als kulturelle Herausforderung. In V. Steinkellner (Ed.), Management-Reihe corporate social responsibility. CSR und Kultur. Corporate cultural responsibility als Erfolgsfaktor in Ihrem Unternehmen (pp. 41-70). Berlin Heidelberg: Springer.

Brooks, S., Klumpe, J., \& Puls, H. (2016). In-office U\&A and purchase process of pens and marker: Step 2 - quantitative findings. Final Report.

Brugger, F. (2010). Nachhaltigkeit in der Unternehmenskommunikation: Bedeutung, Charakteristika und Herausforderungen. SpringerLink: Bücher. Wiesbaden: Gabler Verlag.

Bruhn, M. (2015). Kommunikationspolitik für Industriegüter - ein Überblick. In K. Backhaus (Ed.), SpringerLink: Bücher. Handbuch Business-to-business-marketing. Grundlagen, Geschäftsmodelle, Instrumente des Industriegütermarketing (2nd ed., pp. 337-363). Wiesbaden: Gabler

Buchholtz, A. K., Brown, J. A., \& Shabana, K. M. (2009). Corporate governance and corporate social responsibility. In A. Crane, D. Matten, A. McWilliams, J. Moon, \& D. S. Siegel (Eds.), The Oxford handbook of corporate social responsibility (pp. 327-345). Oxford: Oxford University Press.

Budt, M., \& Lügger, K. (2013). Vertriebsmanagement für Industriegüter. In L. Binckebanck, A.-K. Hölter, \& A. Tiffert (Eds.), Führung von Vertriebsorganisationen. Strategie - Koordination - Umsetzung (pp. 67-90). Wiesbaden: Springer Fachmedien Wiesbaden

Cadden, T., Marshall, D., \& Cao, G. (2013). Opposites attract: Organisational culture and supply chain performance. Supply Chain Management: An International Journal, 18(1), 86-103. https://doi.org/10.1108/13598541311293203.

Campbell, A. (2015). Mission. In C. L. Cooper (Ed.), Wiley encyclopedia of management. Chichester: Wiley.
Carroll, A. B. (2016). Carroll's pyramid of CSR: Taking another look. International Journal of Corporate Social Responsibility, 1(1), 446. https://doi.org/10.1186/ s40991-016-0004-6.

Carter, C. R., \& Rogers, D. S. (2008). A framework of sustainable supply chain management: Moving toward new theory. International Journal of Physical Distribution \& Logistics Management, 38(5), 360-387. https://doi.org/10.1108/ 09600030810882816.

Chao, P., Polonsky, M., \& Jevons, C. (2009). Global branding and strategic CSR: An overview of three types of complexity. International Marketing Review, 26(3), 327-347. https://doi.org/10.1108/02651330910960816.

Chapanis, A. (2004). National and cultural variables in ergonomics. In M. Kaplan (Ed.), Advances in human performance and cognitive engineering research: Vol. 4. Cultural ergonomics (pp. 1-29). Bingley: Emerald.

Choi, D. Y., \& Gray, E. R. (2008). The venture development processes of "sustainable" entrepreneurs. Management Research News, 31(8), 558-569. https://doi.org/10.1108/01409170810892127.

Chuan, P., Khachidze, V., Lai, I. K. W., Liu, Y., Siddiqui, S., \& Wang, T. (Eds.). (2013). Contributions to economics. Innovation in the high-tech economy. Heidelberg: Springer.

Cox, W. M., \& Alm, R. (2018). Creative destruction. In D. R. Henderson (Ed.), Library of economics and liberty. The concise encyclopedia of economics. Liberty Fund, Inc Retrieved from http://www.econlib.org/library/Enc/CreativeDestruction.html.

Crane, A., McWilliams, A., Matten, D., Moon, J., \& Siegel, D. S. (2009). The corporate social responsibility agenda. In A. Crane, D. Matten, A. McWilliams, J. Moon, \& D. S. Siegel (Eds.), The Oxford handbook of corporate social responsibility (pp. 3-18). Oxford University Press.

Cropley, A. J. (2005). Qualitative Forschungsmethoden: Eine praxisnahe Einführung (2. überarbeitete Auflage). Eschborn bei Frankfurt am Main: Klotz.

Cubillo-Guevara, A. P., Hidalgo-Capitán, A. L., \& García-Álvarez, S. (2016). El Buen Vivir como alternativa al desarrollo para América Latina. Revista iberoamericana de estudios de desarrollo = Iberoamerican journal of development studies (IJDS), 5(2). https://doi.org/10.26754/ojs_ried/ijds.184.

Daneshpour, H., \& Takala, J. (2016). The key drivers of sustainability. In C. K. M. Lee (Ed.), International Conference on Industrial Engineering and Engineering Management (IEEM) 2016 (pp. 1205-1209). Piscataway: IEEE.

Davis, J. M., Mora-Monge, C., Quesada, G., \& Gonzalez, M. (2014). Crosscultural influences on e-value creation in supply chains. Supply Chain Management: An International Journal, 19(2), 187-199. https://doi.org/10. 1108/SCM-03-2013-0074

Deckert, C. (2016). Nachhaltige Logistik. In C. Deckert (Ed.), Management-Reihe corporate social responsibility. CSR und Logistik. Spannungsfelder green logistics und City-Logistik (pp. 3-44). Berlin: Springer Gabler.

Deppermann, A. (2001). Gespräche analysieren: Eine Einführung (2. durchgesehene Auflage). Qualitative Sozialforschung: Vol. 3. Opladen: Leske \& Budrich.

Dessein, J., Soini, K., Fairclough, G., \& Horlings, L. (Eds.). (2015). Culture in, for and as sustainable development: Conclusions from the COST Action IS1007 investigating cultural sustainability. IS1007. Retrieved from http://www. culturalsustainability.eu/conclusions.pdf.

d'Heur, M. (2014a). shared.value.chain: Profitables Wachstum durch nachhaltig gemeinsame Wertschöpfung. In M. d'Heur (Ed.), Management-Reihe corporate social responsibility. CSR und value chain management. Profitables Wachstum durch nachhaltig gemeinsame Wertschöpfung (pp. 1-122). Berlin: Springer Gabler.

d'Heur, M. (Ed.). (2014b). Management-Reihe Corporate Social Responsibility. CSR und Value Chain Management: Profitables Wachstum durch nachhaltig gemeinsame Wertschöpfung. Berlin: Springer Gabler.

Di Norcia, V. (1991). Managing across borders: Managing across borders: New organizational responses. The Academy of Management Review, 16(1), 225228. https://doi.org/10.2307/258620.

Disselkamp, M. (2012). Innovationsmanagement: Instrumente und Methoden zur Umsetzung im Unternehmen (2. Aufl. 2012). Wiesbaden: Springer Gabler.

Eggert, A., Haas, A., Ulaga, W., \& Terho, H. (2015). Wertbasiertes Verkaufen auf Industriegütermärkten. In K. Backhaus (Ed.), SpringerLink: Bücher. Handbuch Business-to-Business-Marketing. Grundlagen, Geschäftsmodelle, Instrumente des Industriegütermarketing (2nd ed., pp. 484-498). Wiesbaden: Gabler.

Elkington, J. (1994). Towards the sustainable corporation: Win-win-win business strategies for sustainable development. California Management Review, 36(2), 90-100. https://doi.org/10.2307/41165746.

Elkington, J. (2002). Cannibals with forks: The triple bottom line of 21st century business. Oxford: Capstone.

Ellson, T. (2004). Culture and positioning as determinants of strategy. Basingstoke: Palgrave Macmillan. 
Engert, S., \& Baumgartner, R. J. (2016). Corporate sustainability strategy - Bridging the gap between formulation and implementation. Journal of Cleaner Production, 113, 822-834. https://doi.org/10.1016/j.jclepro.2015.11.094.

Engert, S., Rauter, R., \& Baumgartner, R. J. (2016). Exploring the integration of corporate sustainability into strategic management: A literature review. Journal of Cleaner Production, 112, 2833-2850. https://doi.org/10.1016/j.jclepro.2015.08.031.

Erek, K., Schmidt, N.-H., \& Löser, F. (2013). Nachhaltigkeitsorientiertes ITManagement bei einem internen IT-Dienstleister. In R. Zarnekow \& L. Kolbe (Eds.), SpringerLink: Bücher. Green IT. Erkenntnisse und Best Practices aus Fallstudien (pp. 155-174). Berlin: Springer Gabler.

Fatheuer, T. (2011). Buen Vivir: Eine kurze Einführung in Lateinamerikas neue Konzepte zum guten Leben und zu den Rechten der Natur. Schriften zur Ökologie: Bd. 17. Berlin: Heinrich-Böll-Stiftung Retrieved from https://www. boell.de/sites/default/files/Endf_Buen_Vivir.pdf.

Finch, N. (2015). Development of sustainability reporting frameworks: The case of Australia. In S. O. Idowu, C. S. Frederiksen, A. Y. Mermod, \& M. E. J. Nielsen (Eds.), CSR, sustainability, ethics \& governance. Corporate social responsibility and governance. Theory and practice (pp. 227-240). Cham, Heidelberg, New York, Dordrecht, London: Springer.

Fischer, K. (2017). Corporate sustainability governance: Nachhaltigkeitsbezogene Steuerung von Unternehmen in einer globalisierten Welt. Theorie und Praxis der Nachhaltigkeit. Wiesbaden: Springer Spektrum.

Flick, U. (2006). Qualitative Sozialforschung: Eine Einführung (4. Auflage, vollständig überarbeitet und erweiterte Neuausgabe). Rororo Rowohlts Enzyklopädie: Vol. 55654. Reinbek bei Hamburg: Rowohlt-Taschenbuch-Verlag.

Flick, U. (2011). Triangulation: Eine Einführung (3. Aufl.). Qualitative Sozialforschung: Vol. 12. Wiesbaden: VS Verlag für Sozialwissenschaften.

Flick, U., Kardorff, E., \& Steinke, I. (Eds.). (2005). Rororo Rowohlts Enzyklopädie: Vol. 55628. Qualitative Forschung: Ein Handbuch. Reinbek bei Hamburg: RowohltTaschenbuch-Verlag.

Frostell, B. (2013). Life cycle thinking for improved resource management: LCA or? In J. Kauffman \& K.-M. Lee (Eds.), Handbook of sustainable engineering (pp. 837-858). New York: Springer.

Fürst, M. (2014). Opening the door to opportunities: How to design CR strategies that optimize impact for business and society. In C. Weidinger, R. Schmidpeter, \& F. Fischler (Eds.), CSR, sustainability, ethics et governance. Sustainable entrepreneurship. Business success through sustainability (pp. 155-176). Berlin: Springer.

Garner, B. (2016). The politics of cultural development: Trade, cultural policy and the UNESCO convention on cultural diversity. Routledge studies in culture and sustainable development. Abingdon, New York: Routledge.

Gassmann, O., \& Sutter, P. (Eds.). (2016). Digitale Transformation im Unternehmen gestalten: Geschäftsmodelle, Erfolgsfaktoren, Handlungsanweisungen, Fallstudien. München: Hanser.

Gast, J., Gundolf, K., \& Cesinger, B. (2017). Doing business in a green way: A systematic review of the ecological sustainability entrepreneurship literature and future research directions. Journal of Cleaner Production, 147, 44-56. https://doi.org/10.1016/j.jclepro.2017.01.065.

Gauthier, C. (2005). Measuring corporate social and environmental performance: The extended life-cycle assessment. Journal of Business Ethics, 59(1-2), 199-206. https://doi.org/10.1007/s10551-005-3416-X.

Gemechu, E. D., Sonnemann, G., Remmen, A., Frydendal, J., \& Jensen, A. A. (2015) How to implement life cycle management in business? In G. Sonnemann \& M. Margni (Eds.), LCA compendium - The complete world of life cycle assessment. Life cycle management (pp. 35-50). Dordrecht: Springer Netherlands.

Gerner, M. (2013). Lead agency: UNESCO's global leadership and co-ordination role for the United Nations decade of education for sustainable development (Band 17). Peter Lang Publishing Group.

Giarrizzo, P. (Ed.). (2017). Sonderausgabe "Nachhaltigkeit". pbsreport, (2). Frankfurt am Main: Zarbock Media GmbH \& Co. KG.

Gioia, D. A., Corley, K. G., \& Hamilton, A. L. (2013). Seeking qualitative rigor in inductive research. Organizational Research Methods, 16(1), 15-31. https://doi. org/10.1177/1094428112452151.

Giudice, F. (2013). Eco-packaging development: Integrated design approaches. In J. Kauffman \& K.-M. Lee (Eds.), Handbook of sustainable engineering (pp. 323350). New York: Springer.

Glaser, J., \& Hassler, R. (2015). Sustainability and business success. Management summary. Munich: Retrieved from http://www.oekom-research.com/ homepage/english/study_TUM_oekom.pdf.

Gläser, J., \& Laudel, G. (2012). Experteninterviews und qualitative Inhaltsanalyse als Instrumente rekonstruierender Untersuchungen. Lehrbuch. Wiesbaden: VS Verlag für Sozialwissenschaften.
Glauner, F. (2016). CSR und Wertecockpits: Mess- und Steuerungssysteme der Unternehmenskultur (2., vollständig überarbeitete Auflage). Management-Reihe Corporate Social Responsibility. Berlin: Springer Gabler.

Gold, S., Seuring, S., \& Beske, P. (2010). The constructs of sustainable supply chain management - A content analysis based on published case studies. Progress in Industrial Ecology, An International Journal, 7(2), 114. https://doi.org/10. 1504/PIE.2010.036045.

Gordon, G., \& Nelke, A. (Eds.). (2017). Management-Reihe Corporate Social Responsibility. CSR und Nachhaltige Innovation: Zukunftsfähigkeit durch soziale, ökonomische und ökologische Innovationen. Berlin: Springer Gabler.

Graafland, J., \& Smid, H. (2012). Drivers of corporate social responsibility. In B. C. J. Zoeteman (Ed.), Sustainable development drivers. The role of leadership in government, business and NGO Performance (pp. 156-183). Cheltenham: Edward Elgar.

GREEN BRANDS Organisation GmbH. (2017). Germany 2016 / 2017: Green brands. Retrieved from http://www.green-brands.org/en/germany-20162017-brands-en/.

Grimm, J., \& Saner, R. (2011). Umweltkonflikte und Nachhaltigkeit in Lateinamerika: Verhandlungen zwischen Unternehmen, NGOs und Regierungsstellen. Saarbrücken: Südwestdeutscher Verlag für Hochschulschriften Retrieved from http://diplomacydialogue.org/images/files/20180127Umweltkonfllike\%20in\%20L.A.\%20Saner\%20Grimm.pdf.

Gundry, L. K., \& Kickul, J. R. (2007). Strategies for evaluating opportunities: The assessment process. In L. K. Gundry \& J. R. Kickul (Eds.), Entrepreneurship strategy. Changing patterns in new venture creation, growth, and reinvention (pp. 60-96). Thousand Oaks: Sage Publications. https://www.sagepub.com/ sites/default/files/upm-binaries/10994_Chapter_3.pdf.

Guo, R. (2015). Cross-border management: Theory, method and application. Berlin: Springer.

Habisch, A. (2016). Closing remarks: Practical wisdom as a global research project in the twenty-first century. In A. Habisch \& R. Schmidpeter (Eds.), CSR, sustainability, ethics \& governance. Cultural roots of sustainable management. Practical wisdom and corporate social responsibility (pp. 195-197). Cham: Springer International Publishing.

Habisch, A., \& Bachmann, C. (2016). Empowering practical wisdom: Spiritual traditions and their role in the global business world of the twenty-first century. In A. Habisch \& R. Schmidpeter (Eds.), CSR, sustainability, ethics \& governance. Cultural roots of sustainable management. Practical wisdom and corporate social responsibility (pp. 9-22). Cham: Springer International Publishing.

Habisch, A., \& Schmidpeter, R. (Eds.). (2016). CSR, sustainability, ethics \& governance. Cultural roots of sustainable management: Practical wisdom and corporate social responsibility. Cham: Springer International Publishing.

Habisch, A., Schmidpeter, R., \& Neureiter, M. (Eds.). (2008). Handbuch corporate citizenship: Corporate social responsibility für manager. Berlin: Springer.

Hamilton, C. T. (2011). Sustainability accounting and reporting. In N. R. Khalili (Ed. ), Practical sustainability. From grounded theory to emerging strategies (pp. 183-206). Basingstoke: Palgrave Macmillan.

Handfield, R. B. (2013). Embracing global logistics complexity to drive market advantage. Trends and strategies in logistics and supply chain management. Hamburg: DW Media Group.

Hansen, E. G., \& Große-Dunker, F. (2013). Sustainability-oriented innovation. In S. O. Idowu, N. Capaldi, L. Zu, \& A. D. Gupta (Eds.), Encyclopedia of corporate social responsibility (pp. 2407-2417). Berlin: Springer.

Hansen, E. G., Große-Dunker, F., Reichwald, \& Ralf. (2009). Sustainability innovation cube: A framework to evaluate sustainability of product innovations. International Journal of Innovation Management, 13(04), 683-713. https://doi. org/10.1142/S1363919609002479.

Harps, L. H. (2003). Global logistics: Bridging the cultural divide. Retrieved from http://www.inboundlogistics.com/cms/article/global-logistics-bridging-thecultural-divide/.

Helfferich, C. (2011). Die Qualität qualitativer Daten: Manual für die Durchführung qualitativer Interviews (4. Aufl.). Lehrbuch. Wiesbaden: VS Verl. für Sozialwiss.

Hemmers, B. (2006). Mehr-Werte im Mittelstand. In T. Beschorner (Ed.), Schriftenreihe für Wirtschafts- und Unternehmensethik: Vol. 15. Unternehmerische Verantwortung in Zeiten kulturellen Wandels (1st ed., pp. 127-148). München: Hampp.

Herlyn, E. L. A., \& Radermacher, F. J. (2014). Was kann das Marketing für die Nachhaltigkeit tun? In H. Meffert, P. Kenning, \& M. Kirchgeorg (Eds.), Sustainable marketing management. Grundlagen und Cases (pp. 431-464). Wiesbaden: Gabler. 
Herrmann, C. (2010). Ganzheitliches life cycle management. Berlin: Springer.

Hill, T., \& Westbrook, R. (1997). SWOT analysis: It's time for a product recall. Long Range Planning, 30(1), 46-52. https://doi.org/10.1016/S0024-6301(96)00095-7.

Hilty, R. M., Jaeger, T., \& Lamping, M. (Eds.). (2012). MPI studies on intellectual property and competition law: Vol. 17. Herausforderung Innovation: Eine interdisziplinäre Debatte. Berlin: Springer-Verlag.

Hockerts, K., \& Wüstenhagen, R. (2010). Greening goliaths versus emerging Davids - Theorizing about the role of incumbents and new entrants in sustainable entrepreneurship. Journal of Business Venturing, 25(5), 481-492. https://doi. org/10.1016/j.jbusvent.2009.07.005.

Hoffmann, E., \& Hoffmann, E. C. (2012). User integration in sustainable product development: Organisational learning through boundary-spanning processes. Sheffield: Greenleaf Publishing Limited.

Hoffmann, E., Knopf, J., Rotter, M., \& Richter, I. (2011). Unternehmen, Nachhaltigkeit und Innovation: Empirische Befunde. In J. Knopf (Ed.), Nachhaltigkeitsstrategien in Politik und Wirtschaft: Treiber für Innovation und Kooperation? (pp. 221-239). München: oekom verlag.

Hofstede, G. H., Hofstede, G. J., \& Minkov, M. (2010). Cultures and organizations: Software of the mind: Intercultural cooperation and its importance for survival (Revised and expanded 3rd edition). New York: McGraw-Hill.

Homburg, C. (2017). Marketingmanagement: Strategie - Instrumente - Umsetzung Unternehmensführung (6. Aufl. 2017). Wiesbaden: Springer Fachmedien.

Hopf, C. (2005). Forschungsethik und qualitative Forschung. In U. Flick, E. von Kardorff, \& I. Steinke (Eds.), Rororo Rowohlts Enzyklopädie: Vol. 55628. Qualitative Forschung. Ein Handbuch (pp. 589-600). Reinbek bei Hamburg: Rowohlt-Taschenbuch-Verlag.

Horbach, J. (2005). Indicator systems for sustainable innovation. Sustainability and innovation. Heidelberg, New York: Physica-Verlag.

Hudson, S. (2005). Cultural affects on the global supply chain. Retrieved from https://scm.ncsu.edu/scm-articles/article/cultural-affects-on-the-global-supplychain.

Idowu, S. O., Capaldi, N., Zu, L., \& Gupta, A. D. (Eds.). (2013). Encyclopedia of corporate social responsibility. Berlin: Springer.

Ingram, T. N., Lee, K. S., \& Lucas, G. H. (1991). Commitment and involvement: Assessing a salesforce typology. Journal of the Academy of Marketing Science, 19(3), 187-197. https://doi.org/10.1007/BF02726495.

Jastram, S. (2012). Legitimation privater Governance: Chancen und Probleme am Beispiel von ISO 26000. SpringerLink: Bücher. Wiesbaden: Gabler Verlag.

Jeurissen, R. (2000). John Elkington, cannibals with forks: The triple bottom line of 21st century business. Journal of Business Ethics, 23(2), 229-231. https://doi. org/10.1023/A:1006129603978

Jørgensen, A., Le Bocq, A., Nazarkina, L., \& Hauschild, M. (2008). Methodologies for social life cycle assessment. The International Journal of Life Cycle Assessment, 13(2), 96-103. https://doi.org/10.1065/lca2007.11.367.

Kagan, S., \& Kirchberg, V. (2016). Music and sustainability: Organizational cultures towards creative resilience - A review. Journal of Cleaner Production, 135, 1487-1502. https://doi.org/10.1016/j.jclepro.2016.05.044.

Kaplan, M. (2004). Introduction: Adding a cultural dimension to human factors. In M. Kaplan (Ed.), Advances in human performance and cognitive engineering research: Vol. 4. Cultural ergonomics (pp. XI-XVII). Bingley: Emerald.

Keinert, C. (2008). Corporate social responsibility as an international strategy. Contributions to economics. Heidelberg: Physica-Verlag.

Kenning, P. (2014). Sustainable Marketing - Definition und begriffliche Abgrenzung. In H. Meffert, P. Kenning, \& M. Kirchgeorg (Eds.), Sustainable marketing management. Grundlagen und cases (pp. 3-20). Wiesbaden: Gabler.

Kesting, T., Kliewe, T., Korff, N., \& Serbin, D. (2014). Organisational marketing Making use of linkages and transfer potential between marketing discipline. In T. Kliewe \& T. Kesting (Eds.), SpringerLink: Bücher. Moderne Konzepte des organisationalen marketing. Modern concepts of organisational marketing (pp. 3-22). Wiesbaden: Springer Gabler.

Keuper, F., Hamidian, K., Verwaayen, E., Kalinowski, T., \& Kraijo, C. (Eds.). (2013). SpringerLink : Bücher. Digitalisierung und innovation: Planung - Entstehung Entwicklungsperspektiven. Wiesbaden: Springer Gabler.

Khalili, N. R. (Ed.). (2011a). Practical sustainability: From grounded theory to emerging strategies. Basingstoke: Palgrave Macmillan.

Khalili, N. R. (2011b). Sustainability measurement, assessment, and reporting. In N. R. Khalili (Ed.), Practical sustainability. From grounded theory to emerging strategies (pp. 133-158). Basingstoke: Palgrave Macmillan.

Khalili, N. R. (2011c). Business case for sustainability. In N. R. Khalili (Ed.), Practical sustainability. From grounded theory to emerging strategies (pp. 79-99). Basingstoke: Palgrave Macmillan.
Khalili, N. R., Melaragno, W., \& Haddadian, G. (2011). Promoting sustainable consumption. In N. R. Khalili (Ed.), Practical sustainability. From grounded theory to emerging strategies (pp. 207-224). Basingstoke: Palgrave Macmillan.

Kirchhof, A.-K., \& Nickel, O. (Eds.). (2014). Management-Reihe corporate social responsibility. CSR und brand management: Marken nachhaltig führen. Berlin: Springer Gabler.

Klarmann, M., \& Fleischmann, S. (2014). B-to-B-Branding - Aktuelle Entwicklungen in der Forschung und Praxisempfehlungen. In T. Kliewe \& T. Kesting (Eds.), SpringerLink : Bücher. Moderne Konzepte des organisationalen marketing. Modern concepts of organisational marketing (pp. 337-356). Wiesbaden: Springer Gabler.

Kliewe, T., \& Kesting, T. (Eds.). (2014). SpringerLink: Bücher. Moderne Konzepte des organisationalen Marketing: Modern concepts of organisational marketing. Wiesbaden: Springer Gabler.

Kloepffer, W. (2008). Life cycle sustainability assessment of products. The International Journal of Life Cycle Assessment, 13(2), 89-95. https://doi.org/10. 1065/lca2008.02.376.

Klöpffer, W., \& Grahl, B. (2014). Life cycle assessment (LCA): A guide to best practice. Weinheim: Wiley-VCH Retrieved from http://onlinelibrary.wiley.com/book/10. 1002/9783527655625

Knopf, J. (Ed.). (2011). Nachhaltigkeitsstrategien in Politik und Wirtschaft: Treiber für Innovation und Kooperation? München: oekom verlag.

Kollmann, T., \& Hensellek, S. (2016). Die Basisarchitektur digitaler Geschäftsmodelle. In R. Gläß \& B. Leukert (Eds.), Handel 4.0: Die Digitalisierung des Handels - Strategien, Technologien, Transformation (pp. 59-74). Berlin: Springer Science and Business Media; Springer Gabler.

Kollmann, T., \& Schmidt, H. (2016). Deutschland 4.0: Wie die Digitale Transformation gelingt. SpringerLink: Bücher. Wiesbaden: Gabler.

Komoto, H., \& Mishima, N. (2013). Life cycle simulation for sustainable product service systems. In J. Kauffman \& K.-M. Lee (Eds.), Handbook of sustainable engineering (pp. 633-652). New York: Springer.

Krause, D. E. (Ed.). (2013). Kreativität, innovation, entrepreneurship. Wiesbaden: Springer Fachmedien.

Krause, H.-U. (2016). Ganzheitliches Reporting als Management-Instrument: Ein kennzahlenbasierter Ansatz zur Nachhaltigkeits-Implementierung. De Gruyter Studium. Berlin: De Gruyter Oldenbourg.

Krechovská, M., \& Procházková, P. T. (2014). Sustainability and its integration into corporate governance: Focusing on corporate performance management and reporting. Procedia Engineering, 69, 1144-1151. https://doi.org/10.1016/j. proeng.2014.03.103.

Krieger, M. H. (1972). Social indicators and the life cycle. Socio-Economic Planning Sciences, 6(3), 305-317. https://doi.org/10.1016/0038-0121(72)90035-3.

Kromrey, H. (2002). Empirische Sozialforschung: Modelle und Methoden der standardisierten Datenerhebung und Datenauswertung (10., vollständig überarbeitete Auflage). Uni-Taschenbücher: Vol. 1040. Wiesbaden: VS Verlag für Sozialwissenschaften.

Kuckartz, U. (2014). Mixed Methods: Methodologie, Forschungsdesigns und Analyseverfahren. Wiesbaden: Springer VS.

Kuckartz, U. (2016). Qualitative Inhaltsanalyse. Methoden, Praxis, Computerunterstützung (3., durchgesehene Aufl.). Grundlagentexte Methoden. Weinheim: Beltz Juventa.

Kwak, M., \& Kim, H. (2013). Economic and environmental impacts of product service lifetime: A life-cycle perspective. In H. Meier (Ed.), LNPE. Product-service integration for sustainable solutions. Proceedings of the 5th CIRP international conference on industrial product-service systems. Bochum, Germany, March 14th - 15th, 2013 (1st ed., pp. 177-190). New York: Springer.

Lacoste, S. (2016). Sustainable value co-creation in business networks. Industrial Marketing Management, 52, 151-162. https://doi.org/10.1016/j.indmarman. 2015.05.018.

Lahme, G., \& Klenk, V. (2014). Klenk \& Hoursch: Telling the Backstory Transparenz in globalen Wertschöpfungsketten. In M. d'Heur (Ed.), Management-Reihe Corporate Social Responsibility. CSR und Value Chain Management. Profitables Wachstum durch nachhaltig gemeinsame Wertschöpfung (pp. 155-172). Berlin: Springer Gabler.

Lamnek, S. (2005). Qualitative Sozialforschung: Lehrbuch (4. vollständig überarbeitete Auflage). Beltz-PVU. Weinheim: Beltz-Verlag.

Lantos, G. P. (2001). The boundaries of strategic corporate social responsibility. Journal of Consumer Marketing, 18(7), 595-632. https://doi.org/10.1108/ 07363760110410281.

Larson, A. (2011). Sustainability, innovation, and entrepreneurship. Retrieved from http://2012books.lardbucket.org/pdfs/entrepreneurship-andsustainability.pdf. 
Lee, K.-M. (2013). Sustainable products and sustainable production: Introduction. In J. Kauffman \& K.-M. Lee (Eds.), Handbook of sustainable engineering (pp. 261-268). New York: Springer.

Leszczynska, A. (2011). Cultural conditions of sustainable development of organisations. International Journal of Sustainable Economy, 3(3), 341-360. https://doi.org/10.1504/IJSE.2011.041110.

Lewis, R. D. (2000). When cultures collide: Managing successfully across cultures. Nicholas Brealey Publishing.

Lloret, A. (2016). Modeling corporate sustainability strategy. Journal of Business Research, 69(2), 418-425. https://doi.org/10.1016/j.jbusres.2015.06.047.

Lozano, R. (2012). Towards better embedding sustainability into companies' systems: An analysis of voluntary corporate initiatives. Journal of Cleaner Production, 25, 14-26. https://doi.org/10.1016/j.jclepro.2011.11.060.

Lun, Y. H., Lai, K. H., \& Cheng, T. C. E. (2010). Shipping and logistics management. London: Springer.

Machiba, T. (2011). Eco-innovation for enabling resource efficiency and green growth: Development of an analytical framework and preliminary analysis of industry and policy practices. In R. Bleischwitz, P. J. J. Welfens, \& Z. Zhang (Eds.), International economics of resource efficiency (pp. 371-394). Heidelberg: Physica-Verlag HD.

Maki, P. L. (2012). Assessing for learning: Building a sustainable commitment across the institution. Stylus Publishing.

Maletič, M., Maletič, D., \& Gomišček, B. (2012). An organizational sustainability performance measurement framework. In R. A. Rodrigues Ramos, I. Straupe, \& T. Panagopoulos (Eds.), Energy, environmental and structural engineering series: Vol. 1. Recent researches in environment, energy systems and sustainability. Proceedings of the 8th WSEAS international conference on energy, environment, ecosystems and sustainable development (EEESD 12) (pp. 220-225). WSEAS Retrieved from http://www.wseas.us/e-library/conferences/2012/Algarve/ EEESD/EEESD-34.pdf.

Manda, B. M. K., Bosch, H., \& Worrell, E. (2015). Sustainable value creation with life cycle management. In G. Sonnemann \& M. Margni (Eds.), LCA compendium The complete world of life cycle assessment. Life cycle management (pp. 129-148). Dordrecht: Springer Netherlands.

MarketLine (Ed.). (2013a). MarketLine industry profile office services \& supplies in Germany: Germany - Office services \& supplies. Reference code: 0165-2115 (MarketLine Industry Profile). London.

MarketLine (Ed.). (2013b). MarketLine Industry Profile Global Office Services \& Supplies: Global - Office Services \& Supplies. Reference code: 0199-2115 (MarketLine industry profile). London.

MarketLine (Ed.). (2014). MarketLine Industry Profile Office Services \& Supplies in Europe: Europe - Office Services \& Supplies. Reference code: 0201-2115 (MarketLine industry profile). London.

Marsden, R. (2018). The cultural iceberg. Retrieved from https:// rachelmarsdenwords.files.wordpress.com/2015/08/11807619_ 10153426923151291_1691980310425285378_o.png

Matzler, K., Pechlaner, H., \& Renzl, B. (Eds.). (2014). SpringerLink: Bücher. Strategie und Leadership: Festschrift für Hans H. Hinterhuber. Wiesbaden: Springer Gabler.

Maxwell, D., Sheate, W., \& van der Vorst, R. (2006). Functional and systems aspects of the sustainable product and service development approach for industry. Journal of Cleaner Production, 14(17), 1466-1479. https://doi.org/10.1016/j. jclepro.2006.01.028.

Maxwell, D., \& van der Vorst, R. (2003). Developing sustainable products and services. Journal of Cleaner Production, 11(8), 883-895. https://doi.org/10. 1016/S0959-6526(02)00164-6.

Mayring, P. (2002). Einführung in die qualitative Sozialforschung: Eine Anleitung zu qualitativem Denken (5. überarbeitete und neu ausgestattete Auflage). Beltz Studium. Weinheim: Beltz-Verlag.

Mayring, P. (2014). Qualitative content analysis: Theoretical foundation, basic procedures and software solution. Klagenfurt: Beltz-Verlag Retrieved from http://www.ssoar.info/ssoar/bitstream/document/39517/1/ssoar-2014mayring-Qualitative_content_analysis_theoretical_foundation.pdf

Mayring, P. (2015). Qualitative Inhaltsanalyse: Grundlagen und Techniken (12., aktualisierte und überarb. Aufl.). Beltz Pädagogik. Weinheim: Beltz.

Meffert, H., \& Hensmann, J. (2014). Entwicklungsstufen des Nachhaltigkeitsmanagements. In H. Meffert, P. Kenning, \& M. Kirchgeorg (Eds.), Sustainable Marketing Management. Grundlagen und Cases (pp. 21-36). Wiesbaden: Gabler

Meffert, H., Kenning, P., \& Kirchgeorg, M. (Eds.). (2014). Sustainable marketing management: Grundlagen und cases. Wiesbaden: Gabler.
Meffert, H., \& Rauch, C. (2014). Sustainable Branding - Konzept, Wirkungen und empirische Befunde. In H. Meffert, P. Kenning, \& M. Kirchgeorg (Eds.), Sustainable Marketing Management. Grundlagen und Cases (pp. 159-174). Wiesbaden: Gabler.

Mishra, C. S. (2017). Creating and sustaining competitive advantage: Management logics, business models, and entrepreneurial rent. Cham: Springer International Publishing.

Moll, M. (2012). The quintessence of intercultural business communication. Quintessence series. Berlin: Springer.

Moltesen, A., \& Bjørn, A. (2018). LCA and sustainability. In M. Z. Hauschild, R. K. Rosenbaum, \& S. I. Olsen (Eds.), Life cycle assessment. Theory and practice (pp. 43-58). Cham: Springer International Publishing.

Moray, N. (2004). Culture, context and performance. In M. Kaplan (Ed.), Advances in human performance and cognitive engineering research: Vol. 4. Cultural ergonomics (pp. 31-59). Bingley: Emerald.

Morioka, S. N., \& de Carvalho, M. M. (2016). A systematic literature review towards a conceptual framework for integrating sustainability performance into business. Journal of Cleaner Production, 136, 134-146. https://doi.org/10.1016/ j.jclepro.2016.01.104.

Mory, L. (2014). Soziale Verantwortung nach innen: Dimensionen, Wirkungsbeziehungen und Erfolgsgrößen einer internen CSR. Marktorientierte Unternehmensführung und Internetmanagement. Wiesbaden: Springer Gabler.

Müller-Prothmann, T., \& Dörr, N. (2011). Innovationsmanagement. München: Carl Hanser Verlag GmbH \& Co. KG.

Nawrot, K. A. (2014). Capabilities of leapfrogging and catching up of a developing country - Policy implications from theory and practice. International Economics Letters, 3(4), 117-124.

Nidumolu, R., Prahalad, C. K., \& Rangaswami, M. R. (2009). In fünf Schritten zum nachhaltigen Unternehmen. Harvard-Business-Manager, 31(12), 50-63.

Nidumolu, R., Prahalad, C. K., \& Rangaswami, M. R. (2013). Why sustainability is now the key driver of innovation. IEEE Engineering Management Review, 41(2), 30-37. https://doi.org/10.1109/EMR.2013.6601104.

Ny, H., MacDonald, J. P., Broman, G., Yamamoto, R., \& Robèrt, K.-H. (2006). Sustainability constraints as system boundaries: An approach to making lifecycle management strategic. Journal of Industrial Ecology, 10(1-2), 61-77. https://doi.org/10.1162/108819806775545349.

Ny, H., MacDonald, J. P., Broman, G., Yamamoto, R., \& Robèrt, K.-H. (2009). Sustainability constraints as system boundaries. In H.-F. Wang (Ed.), Webbased green products life cycle management systems. reverse supply chain utilization (pp. 51-73). Hershey: Information Science Reference.

Ny, H., \& Robèrt, K.-H. (2006). Sustainability constraints as system boundaries: An approach to making life-cycle management strategic. Journal of Industrial Ecology, 10(1), 61

O'Neill, G. D., Hershauer, J. C., \& Golden, J. S. (2006). The cultural context of sustainability entrepreneurship. Greener Management International, 2006(55), 33-46. https://doi.org/10.9774/GLEAF.3062.2006.au.00005.

Orsato, R. J. (2014). Sustainability strategies: When does it pay to be green? Palgrave Macmillan; INSEAD Business Press.

Osburg, T. H. (2012). Strategische CSR und Kommunikation. In A. Schneider \& R. Schmidpeter (Eds.), Corporate social responsibility. Verantwortungsvolle Unternehmensführung in Theorie und praxis (pp. 469-480). Berlin: Springer.

Paech, N. (2005). Nachhaltigkeit als marktliche und kulturelle Herausforderung. In K. Fichter, N. Paech, \& R. Pfriem (Eds.), Theorie der Unternehmung: Bd. 29. Nachhaltige Zukunftsmärkte. Orientierungen für unternehmerische Innovationsprozesse im 21. Jahrhundert (pp. 57-96). Marburg: Metropolis-Verl.

Pagell, M., \& Wu, Z. (2009). Building a more complete theory of sustainable supply chain management using case studies of ten exemplars. Journal of Supply Chain Management, 45(2), 37-56. https://doi.org/10.1111/j.1745-493X.2009.03162.x.

Pappas, E., Pappas, J., \& Sweeney, D. (2015). Walking the walk: Conceptual foundations of the sustainable personality. Journal of Cleaner Production, 86, 323-334. https://doi.org/10.1016/j.jclepro.2014.08.077.

Picot, A., \& Lorenz, J. (Eds.). (2010). ICT for the next five billion people. Berlin: Springer.

Pizzirani, S., McLaren, S. J., \& Seadon, J. K. (2014). Is there a place for culture in life cycle sustainability assessment? The International Journal of Life Cycle Assessment, 19(6), 1316-1330. https://doi.org/10.1007/s11367-014-0722-5.

Pohl, A. (1996). Leapfrogging bei technologischen Innovationen: Ein Erklärungsansatz auf Basis der Theorie des wahrgenommenen Risikos. nbf neue betriebswirtschaftliche forschung: Vol. 183. Wiesbaden: Springer Fachmedien Wiesbaden $\mathrm{GmbH}$.

Popoli, P. (2011). Linking CSR strategy and brand image. Marketing Theory, 11(4) 419-433. https://doi.org/10.1177/1470593111418795.

Porter, M. E. (1985/2004). The Competitive Advantage: Creating and Sustaining Superior Performance (1st Free Press Export ed.). New York, London: Free Press. 
Porter, M. E., \& Kramer, M. R. (2006). Strategy and society: The link between competitive advantage and corporate social responsibility. Harvard Business Review, 84(12), 78-92. https://doi.org/10.1108/sd.2007.05623ead.006.

Presse- und Informationsamt der Bundesregierung (Ed.). (2011). Nationale Nachhaltigkeitsstrategie: Fortschrittsbericht 2012. Berlin: Retrieved from https:// archiv.bundesregierung.de/resource/blob/997532/370072/

95ae87c6f9fe1 18c0ce324a4aff05d85/2012-05-21-fortschrittsbericht-2012barrierefrei-data.pdf

Prexl, A. (2010). Nachhaltigkeit kommunizieren - nachhaltig kommunizieren: Analyse des Potenzials der Public Relations für eine nachhaltige Unternehmens- und Gesellschaftsentwicklung. SpringerLink: Bücher. Wiesbaden: VS Verlag für Sozialwissenschaften / GWV Fachverlage, Wiesbaden.

Puls, H. (2016). In-office U\&A and purchase process of pens and marker: Step 1 Qualitative findings. Final Report.

Rahdari, A. H., \& Anvary Rostamy, A. A. (2015). Designing a general set of sustainability indicators at the corporate level. Journal of Cleaner Production, 108, 757-771. https://doi.org/10.1016/j.jclepro.2015.05.108.

Romeiro Filho, E. (2015). Brazilian design for sustainability: In search of a local approach. Journal of Cleaner Production, 107, 467-474. https://doi.org/10. 1016/j.jclepro.2014.08.065.

Roth, J. (2016). Wachstumsperspektiven in Zeiten der Digitalisierung: Die Voraussetzungen geschaffen. BusinessPartner PBS - Die Zeitschrift für Handel und Industrie, 11, 60-61 Retrieved from https:/www.pbs-business.de/uploads/pbsbusiness/magazines/6ae7224f459dcb048de1581556403d37e42c9320/epaper/ 2016-11-BusinessPartner-PBS.pdf? $r n d=58106 e e d b 2826$.

Roy, R. (2000). Sustainable product-service systems. Futures, 32(3-4), 289-299. https://doi.org/10.1016/50016-3287(99)00098-1.

Rusnjak, A. (2014). Entrepreneurial Business Modeling: Definitionen - Vorgehensmodell Framework - Werkzeuge - Perspektiven. SpringerLink: Bücher. Wiesbaden: Springer Gabler.

Sabbaghi, N., \& Sabbaghi, O. (2011). Sustainable supply chain management. In N. R. Khalili (Ed.), Practical sustainability. From grounded theory to emerging strategies (pp. 101-120). Basingstoke: Palgrave Macmillan.

Sakao, T. (2013). Engineering PSS (product/service systems) toward sustainability: Review of research. In J. Kauffman \& K.-M. Lee (Eds.), Handbook of sustainable engineering (pp. 597-614). New York: Springer.

Santamaria, L., Escobar-Tello, C., \& Ross, T. (2016). Switch the channel: Using cultural codes for designing and positioning sustainable products and services for mainstream audiences. Journal of Cleaner Production, 123, 16-27. https://doi.org/10.1016/j.jclepro.2015.09.130.

Schallmo, D. (2013). Geschäftsmodell-Innovation: Grundlagen, bestehende Ansätze, methodisches Vorgehen und B2B-Geschäftsmodelle. Wiesbaden: Springer Fachmedien

Schallmo, D., Rusnjak, A., Anzengruber, J., Werani, T., \& Jünger, M. (Eds.). (2017). Schwerpunkt: Business Model Innovation. Digitale Transformation von Geschäftsmodellen: Grundlagen, Instrumente und Best Practices. Wiesbaden: Springer Fachmedien.

Schaltegger, S. (2011a). Von CSR zu corporate sustainability. In B. Sandberg \& K. Lederer (Eds.), Corporate social responsibility in kommunalen Unternehmen (pp. 187-199). Wiesbaden: VS Verlag für Sozialwissenschaften.

Schaltegger, S. (2011 b). Von CSR zu corporate sustainability. Forum CSR International, (01), 52-53. https://doi.org/10.1007/978-3-531-94040-3_11.

Schaltegger, S. (2017). Lohnt sich Nachhaltigkeitsmanagement? Mindsets' "business cases" und Strategie. In T. Wunder (Ed.), Management-Reihe Corporate Social Responsibility. CSR und Strategisches Management. Wie man mit Nachhaltigkeit langfristig im Wettbewerb gewinnt (pp. 81-94). Berlin: Springer Science and Business Media; Springer Gabler.

Schaltegger, S., \& Burritt, R. (2005). Corporate sustainability. In H. Folmer \& T. Tietenberg (Eds.), The international yearbook of environmental and resource economics 2005/06. A survey of current issues (pp. 185-222). Cheltenham: Edward Elgar Pub.

Schaltegger, S., \& Harms, D. (2013). International corporate sustainability barometer: A comparative study of 11 countries. Lüneburg: CSM, Centre for Sustainability Management Retrieved from http://www.leuphana.de/fileadmin/user_ upload/Forschungseinrichtungen/csm/files/Downloads/ InternationalCorporateSustainabilityBarometer.pdf.

Schaltegger, S., Harms, D., \& Windolph, S. E. (2010). Corporate Sustainability Barometer 2010: Wie nachhaltig agieren Unternehmen in Deutschland? (Corporate Sustainability Barometer). Lüneburg.

Schaltegger, S., Hörisch, J., Windolph, S. E., \& Harms, D. (2012). Corporate Sustainability Barometer 2012: Praxisstand und Fortschritt des
Nachhaltigkeitsmanagements in den größten Unternehmen Deutschlands (corporate sustainability barometer). Lüneburg.

Schaltegger, S., \& Petersen, H. (2009). Corporate Social Responsibility (CSR) nachhaltig im Unternehmen verankern: Eine Herausforderung an die Managementbildung. Journal of Social Science Education, 8(3), 67-79. https:// doi.org/10.4119/UNIBI/jsse-v8-i3-1091.

Schaltegger, S., \& Synnestvedt, T. (2002). The link between 'green' and economic success: Environmental management as the crucial trigger between environmental and economic performance. Journal of Environmental Management, 65(4), 339-346. https://doi.org/10.1006/jema.2002.0555.

Schaltegger, S., \& Wagner, M. (2006). Integrative management of sustainability performance, measurement and reporting. International Journal of Accounting, Auditing and Performance Evaluation, 3(1), 1. https://doi.org/10. 1504/IJAAPE.2006.010098.

Schaltegger, S., \& Wagner, M. (2011). Sustainable entrepreneurship and sustainability innovation: Categories and interactions. Business Strategy and the Environment, 20(4), 222-237. https://doi.org/10.1002/bse.682.

Schaltegger, S., Windolph, S. E., Harms, D., \& Hörisch, J. (Eds.). (2014). Eco-efficiency in industry and science: Vol. 31. Corporate sustainability in international comparison: State of practice, opportunities and challenges. Berlin: Springer.

Schmidpeter, R., \& Lewtas, B. (2016). Introduction to practical wisdom and sustainability. In A. Habisch \& R. Schmidpeter (Eds.), CSR, sustainability, ethics \& governance. Cultural roots of sustainable management. Practical wisdom and corporate social responsibility (pp. 1-8). Cham: Springer International Publishing.

Schmidt, C. (2005a). Analyse von Leitfadeninterviews. In U. Flick, E. von Kardorff, \& I. Steinke (Eds.), Rororo Rowohlts Enzyklopädie: Vol. 55628. Qualitative Forschung. Ein Handbuch (pp. 447-456). Reinbek bei Hamburg: RowohltTaschenbuch-Verlag.

Schmidt, C. (2005b). Analyse von Leitfadeninterviews. In U. Flick, E. von Kardorff, \& I. Steinke (Eds.), Rororo Rowohlts Enzyklopädie: Vol. 55628. Qualitative Forschung. Ein Handbuch (pp. 447-456). Reinbek bei Hamburg: RowohltTaschenbuch-Verlag.

Scholz, R. W., \& Tietje, O. (2002). Embedded case study methods: Integrating quantitative and qualitative knowledge. Thousand Oaks: Sage Publications.

Schram, B., \& Schmidpeter, R. (Eds.). (2016). Management-Reihe corporate social responsibility. CSR und Organisationsentwicklung: Die Rolle des Qualitäts- und Changemanagers. Berlin: Springer Gabler.

Schreier, M. (2014). Varianten qualitativer Inhaltsanalyse: Ein Wegweiser im Dickicht der Begrifflichkeiten. Forum Qualitative Sozialforschung / Forum: Qualitative Social Research, 15(1). https://doi.org/10.17169/fqs-15.1.2043.

Schröder, F. R., Holbach, D., \& Müller-Kirschbaum, T. (2014). HENKEL: Nachhaltigkeit in der Wertschöpfungskette - Von der Philosophie zur konkreten Umsetzung. In M. d'Heur (Ed.), Management-Reihe corporate social responsibility. CSR und value chain management. Profitables Wachstum durch nachhaltig gemeinsame Wertschöpfung (pp. 257-268). Berlin: Springer Gabler.

Schuh, G. (2013). Lean innovation. VDI-Buch. Berlin: Springer Vieweg.

Schumpeter, J. A. (1912/2006). Theorie der wirtschaftlichen Entwicklung. Berlin: Duncker \& Humblot.

Seliger, G. (Ed.). (2012). Sustainable production, life cycle engineering and management. Sustainable manufacturing: Shaping global value creation (1., neue Ausg). Berlin: Springer Berlin.

Seuring, S., \& Müller, M. (2008). Core issues in sustainable supply chain management - a Delphi study. Business Strategy and the Environment, 17(8), 455-466. https://doi.org/10.1002/bse.607.

Shister, N. (2004). Managing global relationships in the extended supply chain: The 'soft side' of the cost equation are the human factors you can't account for in advance., 1(17), 14-18.

Silverman, D. (2013). Doing qualitative research (4th ed.). London, Thousand Oaks, New Delhi, Singapore: SAGE Publications Ltd.

Silverman, D. (2014). Interpreting qualitative data (Fifth edition). London: SAGE.

Skjerven, A., \& Reitan, J. B. (Eds.). (2017). Routledge studies in culture and sustainable development. Design for a sustainable culture: Perspectives, practices and education. Abingdon, New York: Routledge.

Smith, E. E., \& Muller, R. J. (2016). Creating a culture of sustainability in organisations in Nelson Mandela Bay. In A. Strasheim, A. Nel, \& E. Koekemoer (Eds.), Managing in resource restricted times make every day matter. Proceedings of the 28th annual conference of the southern African Institute of Management Scientists (pp. 72-87). Pretoria: Retrieved from http://www.up.ac.za/media/shared/643/ZP_Files/2016/Papers/hrl9_full. zp97850.pdf. 
Solomon, C. M., \& Schell, M. S. (2009). Managing across cultures: The seven keys to doing business with a global mindset. New York: McGraw-Hill.

Sommer, B., \& Welzer, H. (2014). Transformationsdesign: Wege in eine zukunftsfähige Moderne. Transformationen: Vol. 1. München: oekom verlag.

Sonnemann, G., Gemechu, E. D., Remmen, A., Frydendal, J., \& Jensen, A. A. (2015). Life cycle management: Implementing sustainability in business practice. In G. Sonnemann \& M. Margni (Eds.), LCA compendium - The complete world of life cycle assessment. Life cycle management (pp. 7-21). Dordrecht: Springer Netherlands.

Sonnemann, G., \& Margni, M. (Eds.). (2015). LCA compendium - The complete world of life cycle assessment. Life cycle management. Dordrecht: Springer Netherlands.

Springer Fachmedien Wiesbaden (Ed.). (2014). 222 Keywords Marketing: Grundwissen für Manager. Dordrecht: Springer Fachmedien Wiesbaden.

Stampfl, G. (2016). The process of business model innovation: An empirical exploration. Research. Wiesbaden: Springer Gabler.

Stanger, S. (2016). Nachhaltigkeit als Treiber des Innovationsprozesses: Analyse der Einflussfaktoren und Konzeption eines nachhaltigen Innovationsmanagements (1., Aufl.). Schriftenreihe Innovative Betriebswirtschaftliche Forschung und Praxis: Vol. 452. Hamburg: Verlag Dr. Kovac.

Stanger, S. (2017). Nachhaltigkeit als Determinante des Innovationserfolgs - ein Systematic-Literature-Review und Entwicklung eines konzeptionellen Modells. In W. Leal Filho (Ed.), Theorie und Praxis der Nachhaltigkeit. Innovation in der Nachhaltigkeitsforschung. Ein Beitrag zur Umsetzung der UNO Nachhaltigkeitsziele (pp. 61-78). Berlin: Springer Spektrum.

Stanley, S. M., \& Markman, H. J. (1992). Assessing commitment in personal relationships. Journal of Marriage and the Family, 54(3), 595. https://doi.org/10.2307/353245.

Steinkellner, V. (Ed.). (2016a). Management-Reihe corporate social responsibility. CSR und Kultur: Corporate cultural responsibility als Erfolgsfaktor in Ihrem Unternehmen. Springer Berlin Heidelberg.

Steinkellner, V. (2016b). Corporate cultural responsibility: Eine Einführung. In V. Steinkellner (Ed.), Management-Reihe corporate social responsibility. CSR und Kultur. Corporate cultural responsibility als Erfolgsfaktor in Ihrem Unternehmen (pp. 3-30). Springer Berlin Heidelberg.

Strati, A. (2000). Theory and method in organization studies: Paradigms and choices. London: Sage Publications.

Strauss, A. L. (1998). Grundlagen qualitativer Sozialforschung: Datenanalyse und Theoriebildung in der empirischen soziologischen Forschung (2. Auflage). UTB für Wissenschaft: 1776, Soziologie. München: Fink (Original work published 1987).

Ternès, A., \& Runge, C. (2015). Reputationsmanagement: Banken. Essentials. Wiesbaden: Springer Fachmedien Wiesbaden.

The Business Zoom. (2015). Schein's model.

The European Federation of Financial Analysts Societies (EFFAS). (2009). KPIs for ESG a guideline for the integration of ESG into financial analysis and corporate valuation: Key performance indicators for environmental, social \& governance issues. Version 1.2. Dreieich.

Tilt, C. A. (2016). Corporate social responsibility research: The importance of context. International Journal of Corporate Social Responsibility, 1(1), 18. https://doi.org/10.1186/s40991-016-0003-7.

Tokarski, K. O., Schellinger, J., \& Berchtold, P. (Eds.). (2016). SpringerLink: Bücher Unternehmensentwicklung: Strategien und Instrumente aus Forschung und Praxis (1. Aufl. 2016). Wiesbaden: Gabler.

Trompenaars, A., \& Hampden-Turner, C. (2012). Riding the waves of culture: Understanding diversity in global business (Rev. and updated 3rd ed.). London: Nicholas Brealey.

United Nations Environment Programme (UNEP). (2012). Measuring progress: Environmental goals \& gaps. Nairobi: Retrieved from United Nations website: http://www.cjwalsh.ie/wp-content/uploads/2012/10/UNEP_MeasuringProgress-Report_2012.pdf.

United Nations Environment Programme (UNEP), \& Delft University of Technology (Eds.) (2006). Design for sustainability: A practical approach (Design for social responsibility series). Retrieved from United Nations website: http://www.d4s-de.org/manual/d4stotalmanual.pdf.

Van den Berghe, Lutgart, Spitzeck, H., Hansen, E. G., \& Grayson, D. (2011). Joint management-stakeholder committees - A new path to stakeholder governance? Corporate Governance: The International Journal of Business in Society (Corporate Governance), 11(5), 560-568. https://doi.org/10.1108/14720701111176975.

van Hemel, C. G. (1998). EcoDesign empirically explored: Design for environment in Dutch small and medium-sized enterprises. 200217. Amsterdam: Boekhandel MilieuBoek.

van Hove, N. (2013). Cultural differences need to be addressed in global S\&OP. Retrieved from https://www.supplychainmovement.com/cultural-differencesneed-to-be-addressed-in-global-sop/ .
Verband der PBS-Markenindustrie im FMI e.V. (2017a). Die Marken. Retrieved from http:/www.pbs-markenindustrie.de/marken?domain=4405 .

Verband der PBS-Markenindustrie im FMl e.V. (2017b). PBS-Markenartikel 2017: Büroartikel überholen Schreibgeräte und Papier. Retrieved from http://www.pbsmarkenindustrie.de/aktuelles/bueroartikel-ueberholen-schreibgeraete-und-papier.

Vezzoli, C., Ceschin, F., Diehl, J. C., \& Kohtala, C. (2015). New design challenges to widely implement 'sustainable product-service systems'. Journal of Cleaner Production, 97, 1-12. https://doi.org/10.1016/j.jclepro.2015.02.061.

Viardot, E. (2017). The timeless principles of successful business strategy: Corporate sustainability as the new driving force (2nd ed. 2017). Management for professionals. Berlin: Springer.

Vishwanath, A., \& Barnett, G. A. (2011). The diffusion of innovations: A communication science perspective. New York: Peter Lang.

Walther, G. (2010). Nachhaltige Wertschöpfungsnetzwerke: Überbetriebliche Planung und Steuerung von Stoffströmen entlang des Produktlebenszyklus. Produktion und Logistik. Wiesbaden: Gabler Verlag / GWV Fachverlage.

Weber, J., Bramsemann, U., Heineke, C., \& Hirsch, B. (2017). Wertorientierte Unternehmenssteuerung: Konzepte - Implementierung - Praxis-Statement (2. überarbeitete Aufl. 2017). SpringerLink: Bücher. Wiesbaden: Springer Gabler.

Weber, T. (2015). CSR und Produktmanagement: Langfristige Wettbewerbsvorteile durch nachhaltige Produkte. Management-Reihe Corporate Social Responsibility. Berlin: Springer Gabler.

WebFinance Inc. (2019a) What are market entrants?: Definition and meaning. Retrieved from http://www.businessdictionary.com/definition/new-entrants.html.

WebFinance Inc. (2019b). What is commoditization?: Definition and meaning. Retrieved from http://www.businessdictionary.com/definition/ commoditization.html.

WebFinance Inc. (2019c). What is digitization?: Definition and meaning. Retrieved from http://www.businessdictionary.com/definition/digitization.html.

Weiber, R., \& Wolf, T. (2014). Entwicklung einer Marketing-Konzeption für das Business- und Dienstleistungsmarketing: Plädoyer für einen integrativen Ansatz. In T. Kliewe \& T. Kesting (Eds.), SpringerLink : Bücher. Moderne Konzepte des organisationalen Marketing. Modern Concepts of Organisational Marketing (pp. 23-42). Wiesbaden: Springer Gabler.

Weidinger, C., \& Schmidpeter, R. (2014). Linking business and society: An overview. In C. Weidinger, R. Schmidpeter, \& F. Fischler (Eds.), CSR, sustainability, ethics et governance. Sustainable entrepreneurship. Business success through sustainability (pp. 1-12). Berlin: Springer.

Weidinger, C., Schmidpeter, R., \& Fischler, F. (Eds.). (2014). CSR, sustainability, ethics et governance. Sustainable entrepreneurship: Business success through sustainability. Berlin: Springer.

Weihrich, H. (1982). The TOWS matrix - A tool for situational analysis. Long Range Planning, 15(2), 54-66. https://doi.org/10.1016/0024-6301(82)90120-0.

Weinreich, U. (2016). Lean Digitization: Digitale Transformation durch agiles Management (1. Aufl. 2016). Berlin: Springer Berlin Heidelberg.

Welfens, P. J. J., Perret, J. K., \& Erdem, D. (2011). Global economic sustainability Indicator: Analysis and policy options for the Copenhagen process. In R. Bleischwitz, P. J. J. Welfens, \& Z. Zhang (Eds.), International economics of resource efficiency (pp. 19-50). Heidelberg: Physica-Verlag HD.

Wilson, M. (2003). Corporate sustainability: What is it and where does it come from? Ivey Business Journal March/April. Retrieved from https:// iveybusinessjournal.com/publication/corporate-sustainability-what-is-it-andwhere-does-it-come-from/.

Woeckener, B. (2014). Strategischer Wettbewerb: Eine Einführung in die Industrieökonomik (3., überarb. u. erg. Aufl. 2014). Springer-Lehrbuch. Berlin: Springer Gabler.

Wong, H.-K., \& Ellis, P. D. (2007). Is market orientation affected by the product life cycle. Journal of World Business (JWB), 42(2), 145-156 Retrieved from https:// effectsizefaq.files.wordpress.com/2011/03/wong-and-ellis-2007-mo-and-theplc-jwb-422.pdf.

Wunder, T. (2017). Nachhaltiges Strategisches Management: Anknüpfungspunkte und Impulse für die praktische Strategiearbeit. In T. Wunder (Ed.), Management-Reihe Corporate Social Responsibility. CSR und Strategisches Management. Wie man mit Nachhaltigkeit langfristig im Wettbewerb gewinnt (pp. 1-44). Berlin: Springer Science and Business Media; Springer Gabler.

Zarnekow, R., \& Kolbe, L. (Eds.). (2013). SpringerLink: Bücher. Green IT: Erkenntnisse und Best Practices aus Fallstudien. Berlin: Springer Gabler.

\section{Publisher's Note}

Springer Nature remains neutral with regard to jurisdictional claims in published maps and institutional affiliations. 